\title{
TÜMEVARIM MESELESI
}

- İBN SÎNÂ MERKEZLİ YENİ BİR OKUMA -*

Mevlüt UYANIK **

\section{Özet}

Felsefenin amacı, insan mutluluğunu temin etmektir (tahsilu's-saade). Mantık da bunu temin edecek felsefenin anahtarıdır. Mantık, tikelden tümele, bilinenden bilinmeyene yönelerek hüküm çıkarıp mutluluğu temin edecek bilgiyi rasyonel, tutarlı bir şekilde kazandıracaktır. Zira dil ile düşünce arasında ilişkinin tutarlı ve doğru bir şekilde kurulması akıl yürütmenin akıl ilkelerine (özdeşlik, çelişmezlik, üçüncü halin imkânsızlığı) uygun olması demektir. Bu nedenle mantık, felsefî düşüncede önemli bir işlev görmektedir. Yeniçağ felsefesinde modern bilim anlayışında tümevarım yöntemi Bacon ile ön plana çıkarıldı ama daha sonra Hume, günümüzde ise Popper ile birlikte böyle bir yöntemin olmadığı gündeme getirildi. Tümevarım yönteminin bir efsane olduğu söyleminin tutarlığını Muallim-i evvel olan Aristoteles'ten etkilenen İbn Sînâ açısından inceleyip sorunu yeniden müzakereye açmak istedik. Çünkü Bacon'dan önce tümevarım yöntemini inceleyen, onu bilimsel araştırmalarda kullanılacak bir yöntem olarak geliştiren İbn Sînâ'dır. Bilimde ilk ve temel ilkeler olarak tümellerin işlevsel olması, gözlem ve deneyimle desteklenen tümevarımın mutlak ilkeler vermemesinin bilim için gerekli, zorunlu bazı temel ilkeleri verebileceğine engel olup olmadığını araştıracağız. Böylece Hume ve Popper ile birlikte zirveye ulaşan tümevarım sorununun açmazlarının giderilebilme intimalini müzakereye açacağız.

Anahtar kelimeler: Felsefe, mantık, tümevarım, tutarlılık, İbn Sina, Hume, Popper.

\section{Abstract}

\section{The Problem of Induction - Rereading from the point of Avicenna -}

The purpose of philosophy is to achieve happiness. Logic is just like a key leading man towards this joy in philosophy. Logic helps us to reach knowledge on a standart of rationality and coherence by following the path of the individual to the universal and the known through the unknown. An exact correspondence between thoughts and words occur only with correct principles of reasoning. Therefore, logic plays a great role in philosophy. The scientific method 'induction' in the new age philosophy was brought to agenda by Bacon but later it was refuted by many philosophers like Hume and Popper. Before Bacon, the philosopher was İbni Sina who developed "the induction" as a method of scientific researches. In this paper, Ibn Sina's view of induction is discussed. I begin with a brief look at the Aristotelian induction and its critique. I present Ibn Sina's view of induction with a support of experimentation (tacruba). I analysed how induction and experimentation would be the conditional as opposed to absolute principles of natural sciences. To sum up, Ibn-i Sina developed a method of induction and experimentation as a means for scientific inquiry. He thought that the

* Uluslararası İbn Sînâ Sempozyumu'na (22-24.05.2008. İstanbul) sunulan bildirinin Batı felsefesinin verileriyle (Bacon, Hume, Lachelier, Popper) geliştirilmiş şeklidir.

** Prof. Dr., Hitit Ü. İlahiyat Fakültesi 
natural scientist could use experimentation to discover "conditional" principles. The study concludes with some brief comments about the refutation of induction by some thinkers in the history of science and philosophy.

Keywords: Philosophy, logic, induction, coherence, Avicenna, Hume, Popper.

\section{Giriş}

Felsefî düşüncede tümevarım, zihnin tikelden tümele götüren akıl yürütme formu diye tanımlanır. Yeniçağ felsefesinde yöntem sorunu bağlamında incelenen tümevarım ile insan zihnini yeni baştan tanzim etmek, bilimin temellerini yeniden kurgulamak hedeflenir. Tümevarım, bir bütünün parçalarına dayanarak o bütün hakkında hüküm vermektir. Bu, "hafta" gibi her parçasının sayılması mümkün olan bütünler hakkında mümkün olabilir ama deneysel/pozitif bilimlerde kullanılan yöntemlerden biri olarak kullanıldığında pek mümkün olmaz. Zira tümevarımda tabiatın bir düzeni olduğu varsayılarak gözlemlenen olayların benzer şartlarda gelecekte de tekrarlanacağı tahmin edilir. Ne var ki tabiatın düzenliliğini temellendirmek için de tümevarıma muhtaç olunması âlimi döngüselliğe ittiği söylenmektedir. ${ }^{1}$ Hatta David Hume ve S. Karl Popper'den Teo Grünberg'e kadar birçok felsefeci tümevarım diye bir yöntem olmadığını, ${ }^{2}$ onun bir mit ve efsane olduğunu belirtir. Fakat Popper'in “Tümevarım bir efsanedir"3 şeklinde ünlenen hükmünde Aristoteles'in tümdengelimi bir düşünme tarzı olarak görmesi, "tümevarımı ise "duyuma benzer" bir şey olarak tanımlamasının etkisi olabilir. Çünkü o, tümevarımı psikolojik olarak özel hallerin bütünsel bir görünümünü içeren doğrudan bir seziş (insight) işlemi olarak görmüş, dolayısıyla bir akıl yürütme söz konusu olmadığını belirt-

1 Irzık, Gürol, "Yanlışlamacı Bilim Felsefesi: Genel Bir Değerlendirme”, Felsefe Tartışmaları, İstanbul 2001, 28. kitap, s. 22.

2 David Hume, İnsan Zihni Üzerine Bir Araştırma, çev.: Selmin Evrim, Milli Eğitim Bakanlı̆̆ı, İstanbul 1986, ss. 38-39; Reichenbach, Bilimsel Felsefenin Doğuşu, çev.: Cemal Yıldırım, Remzi Kitabevi, İstanbul 1981, s. 68; Teo Grünberg, Felsefe ve Felsefi Mantık Yazılarl, Yapı Kredi Yayınları, İstanbul 2005, ss. 368, 378; Bryan Magee, Karl Popper'in Bilim Felsefesi ve Siyaset Kuram, çev.: Mete Tunçay, Remzi Yay., İstanbul 1990, s. 20; Irzık, agm, ss. 21-24.

3 Bununla matematiksel tümevarımı kastetmediğini özellikle belirtmek gerekir. Çünkü tümevarımın özellikle matematik disiplininde sayılar kuramında yeri ayrıdır. Popper'in kastı, sadece tümevarımsal bilimde, tümevarıma benzer bir şeyin, yani tümevarımsal bir yöntemin var olduğunu reddetmektedir. Karl R. Popper, Bilimsel Araştırmanın Mantığı, çev.: İlknur Aka, İbrahim Turan, Yapı Kredi Yayınları, İstanbul 1998, s. 64; Ali Nesin, Önermeler Mantı̆̆ğ, İstanbul 2004, ss. 49-50. 
miştir. ${ }^{4}$ Tümevarıma dayanan çıkarımlara yöneltilen eleştirilerin İslam felsefesindeki yeri nedir? Bu sorunun cevabını “ilk mantık tarihini yazan, mantık öğrenimi kolaylaştırmak ve yaygınlaştırmak için konuyla ilgili değişik metinler ortaya koyan" kısacası mantık ilmini tertipleyen, düzenleyen eş-Şeyhu'r-Reis Ebû Alî el-Huseyin İbn Sînâ (370/980-428/1037?)5 merkeze alarak müzakere edeceğiz.

İbn Sînâ, iyi delili kötüsünden ayırt etmeyi hedefleyen mantığ kişiye mutluluğu temin etmeyi biricik hedef olarak gören felsefenin anahtarı olarak görür. Roger Bacon'un tespitiyle söyleyecek olursak o, felsefe tarihinde Aristoteles'ten sonraki düşünürdür. $\mathrm{O}$, Aristotelesçi ve Stoacı mantık geleneğini, Fârâbî ve Bağdat mantık ekolü vasıtasıyla tevarüs etmiş ama kendine özgü bir yapı oluşturabilmiş bir filozoftur. ${ }^{6}$ İbn Sînâ, Peripatik düşüncenin yanı sıra Helenistik gelenekten önemli ölçüde etkilenmiş ama Eflatuncu, Proklusçu ve diğer YeniEflatuncu unsurları İslam geleneğinde yeniden ifade etme yollarını aramış, buna dair kendine ait yöntem ve tezler geliştirmiştir. Hatta mantık tarihi aç1sından 11. asra "İbn Sînâ Yüzyılı" denilmektedir. Benzer bir nitelemeyi İslam felsefesi açısından daha genelleyerek söylemek mümkündür. Diğer bir ifadeyle “Ondan önce (Aristotelesçi ve Yeni Eflatuncu anlamdaki) Arapça felsefe ile (doktrinel İslam teolojisi) kelam arasında görüş alışverişi olsa da bunlar birbirinden ayrı alanlardı. İbn Sînâ ile birlikte bu iki alan kaynaşmış, akabinde ke-

4 Arslan, Ahmet, “Aristoteles”, İlkçă̆ Felsefesi Tarihi 3, İstanbul Bilgi Üniversitesi Yay., İstanbul 2007, s. 99.

5 Ali Durusoy, “İbn Sînâ'nın Klasik Mantığa Katkıları”, İslam Felsefesinin Sorunları Sempozyumu Bildirileri, Ankara 2003, ss. 181-192; M. Şemseddin Günaltay, “İbn Sînâ ve Mantık", Büyük Türk Filozof ve Tib Üstadı İbn Sînâ: Şahsiyeti ve Eserleri Hakkında Tetkikler (İbn Sînâ'nın 800 yıldönümü), İstanbul 1957, (ilk basım, İstanbul 1937), s. 2. Hayatı, doğum tarihi, eserleri, mezhebi ve sisteminin özgünlüğü hakkındaki değerlendirmeler için bk. Dimitri Gutas, İbn Sinấnnn Mirası, der.: ve çev.: M. Cüneyt Kaya, Klasik Yay., İstanbul 2004, ss. 1-29, 35, 45, 141; Hanna elFahuri, Halil el-Cür, Tarihu'l-Felsefeti'l-Arabiyye, Beyrut 1982, c. 2, ss. 157 vd.

6 Fazlur Rahman, “İbn Sînâ”; İslam Düşünce Tarihi, ed.: M. M. Şerif, İstanbul 1990, c. 2, ss. 99100, 123-125; H. Ziya Ülken, “İbn Sînâ”, İA, Milli Eğitim Bakanlığı, İstanbul 1968, c. 5/2, s. 821; a. mlf, İslam Düşüncesi, İstanbul 1995, ss. 215-216; Tony Street, "Mantık” İslam Felsefesine Giriş, ed.: P. Adamson, R. Taylor, çev.: Cüneyt Kaya, Küre Yay., İstanbul 2007, s. 273; Michael E. Marmura, "Avicenna", The Encyclopedia of Philisophy, New York 1967, c. 1, ss. 227-229.

Bilim alanında ise Descartes, Leibniz, D’alembert, Thomson, Kirchoff gibi âlimler, onun kavramsallaştırmalarını (hareket ve ölçümü, fizikte temel elementler, 1şık hızı ve ses hızı arasındaki ayrım, zaman-mekân, güç birimi ve içtepi) dikkate alarak araştırmalar yapmışlardır. M. Mirshahi AVICENNA, a universal genius; http://ismaili.net/Source/mi0451d.html (erişim tarihi: 25.05.2012) 
lam, İbn Sînâ'nın metafiziğiyle İslam öğretisinin sentezinden oluşmuş gerçek anlamda bir İslam felsefesi olarak ortaya çıkmıştır."7

Bu bağlamda Bacon'un Aristotelesçi kıyas anlayışının insan zihninin gelişmesini engellediği düşüncesiyle metodik veya deneysel induksiyon adıyla istikra yöntemini geliştirdiği iddiasına ${ }^{8}$ karşı İbn Sînâ'nın ondan önce sofistlerin tutarsızlıklarını gidermek için istikra yöntemini kullanması önemlidir. ${ }^{9}$ Nitekim Bacon'dan önce İbn Sînâ' da bilimsel araştırmanın bir vasıtası olarak gözlem ve deneyimi (tecrübe) bir yöntem olarak geliştirmeye çalışır. Üstelik bunu mutlak ilkeler vermeyeceğini söyleyerek yapar, tabiat bilimcisi gözlem ve deneyimi arızi şartların keşfi için kullanabileceğini, bilimde ilk ilkeler olarak işlevsel olanın tümel, evrensel ilkeler olduğunun bilinciyle söyler. ${ }^{10}$

\section{Felsefe ve Mantık İlişkisi}

Mantık, bilinenden bilinmeyen kavram ve hükümleri çıkarsayarak bilgi derecemizi yükseltir. Bilgisizliğimiz en önemli mutsuzluk ayracıdır; bilerek de kendimizi mutsuz kılacak bir kötülük yapmayacağımıza göre bilgide yükselmek mutluluğun elde edilmesi demektir. Bu teorik açıdan gerçeği bilmek, gücü ölçüsünde eşyanın hakikatine vakıf olmak, pratik açıdan ise 'iyi'yi bilmek ve buna uygun davranmakla mümkün olur.

Teorik felsefe, bilmek suretiyle nefsi yetkinleştirirken pratik felsefede yapılacak şeyleri bilmek suretiyle bu yetkinliği tamamlamak hedeflenir. Buradan hareketle yazıda "Her türlü zihni ve fikri eğitim-öğretim nasıl gerçekleştirilir; bilinenlerden hareketle bilinmeyene, elde edilmek istenene (matlub) ulaşma nasıl olur, tasavvur ve tasdik edilme süreci ve tutarlılığı nedir?" sorularını tartı-

7 Robert Wisnovsky, "İbn Sînâ ve İbn Sînâcı Gelenek" İslam Felsefesine Giriş (The Cambridge Companion to Arabic Philosophy), ed.: Peter Adamson, Richard C. Taylor, çev.: M. C. Kaya, Küre Yay., İstanbul 2007, ss. 103, 109; Nicholas Rescher, The Develepment of Arabic Logic, Pittsburgh 1964, s. 50.

8 Yeniçağın başlangıcından bu yana Bacon, Galile ve Descartes gibi birçok bilim insanı, Aristotelesçi mantığın, yapısı gereği bize eşya hakkında herhangi bir bilgi veremeyeceği olsa olsa ancak zihnimizin kendisi, nasıl çalıştığı ve doğru olarak çalışması için gerekli ilkeleri incelediği üzerinde durulmaktadır. Arslan, age, s. 62; Kulen, Mantık, Kulen Yay., İstanbul 1972, s. 94.

9 Günaltay, agm, ss. 1-13, 18-19; Tahir Yaren, İbn Sînâ Mantığına Giriş, Ankara 2003, s. 8; Marmura, “Avicenna”, c. 1, s. 228; Bağdat ekolü için bk. Rescher, age, s. 33 vd.

10 John Mcginnis, "Scientific Methodologies in Medieval Islam", Journal of the History of Philosophy, vol. 41, issue: 3, Temmuz 2003, s. 307. 
şacağız. ${ }^{11}$

Bu husus, İslam felsefesinde Meş̧̧âi gelenek içinde tartışma konusu yapılır. İbn Sînâ' da "Kendisi bir din olmaksızın dine en yakın felsefî öğretiye sahip" Platon ve "kendisi bir bilim olmaksızın bilime en yakın felsefî öğretiye sahip" Aristoteles'ten önemli oranda etkilenmiştir. Aristotelesçiliğin Platonculuktan ayrıldığı nokta; Platon'un idea kuramının duyusal-bireysel varlıkların dışında ve üstünde olduklarını, onlardan ayrı ve bağımsız bir dünya oluşturduklarını reddetmede yatar. Dolayısıyla duyusal ve tinsel, tümel ile tikel âlemleri birbirine yaklaştırmak hatta birleştirmek gerekir. ${ }^{12} \mathrm{Bu}$ da ancak ideler, duyusalbireysel-tikel varlıkların üstünde veya dışında değil onlara içkin olarak bulunduğunu göstermekle mümkün olur. ${ }^{13}$ Tikelde tümeli yakalamaktan kasit budur.

\section{1. Çıkarsanabilirlik Öğretisi Olarak Mantık}

İnsanı diğer canlılardan ayıran husus, onun konuşmasıdır ki bu, düşünmenin malulü olup insanların anlaşabilmeleri için gereklidir. Mantık terimi, Arapça 'nutk'tan türetilmiş ve "insanın zihninde olan bir anlamı ifade" etme aracı olan söz anlamına gelir. İç konuşma/düşünme ile bunların ifadesi/dış konuşma arasindaki uyum ve uygunluk/tutarlılığa ise mantıklı düşünme denir. İlkelerine uyulduğu takdirde zihni ıslah eder, insanı düşünce de hataya düşme tehlikesinden korur ve hakikate giden doğru yola ulaştırır. Bu açıdan mantık "bir bilme ve bilme gücü"dür, "en önce gelen bir bilim olup onu önceleyen başka bir bilim yoktur. Dolayısıyla mantığı öğrenmek ve uygulamak zorunludur. ${ }^{14}$

11 İbn Sînâ, "el-İlahiyat", Kitâbu'ş-Şîfâ, tahk.: G. C. Kanavati, Said zayed, ts., ss. 4-5;10-11; Mantıku'l-Meşrikiyyin, ss. 5-8; "Mantığa Giriş", Kitâbu'ş-Şiffâ, çev.: Ömer Türker, Litera, İstanbul 2006, ss. 5, 7-10; “II Analitikler/Burhan; İşaretler ve Tenbihler, çev.: A. Durusoy, M. Macit, E. Demirli, İstanbul 2005, s. 2-4; Ali Durusoy, Metinlerle Mantığa Giriş, İstanbul 2006, ss. 311-312; Günaltay, agm, ss. 4, 1, 22; Şemsi İnati, “İbn Sînâ", İslam Felsefesi Tarihi, edit.: S. H. Nasr ve O. Leaman, çev.: Ş. Öçal, H. T. Başoğlu, Açılım Kitap, İstanbul 2007, ss. 280-281.

12 Magee, age, s. 47; Bernard Russel, Felsefede İlmi Metod, çev.: Hamdi Akverdi, İstanbul 1940, ss. 57-58; Doğan Özlem, Siyaset, Bilim ve Tarih Bilinci, İnkilap Yay., İstanbul 1999, s. 55; Orhan Hançerlioğlu, Felsefe Sözlü̈̆̈̈, Remzi Yay., İstanbul 1979, ss. 8, 239.

13 Arslan, "Aristoteles", İlkçă̆ Felsefesi Tarihi 3, ss. 14, 28-29, 79-80; sorunun İbn Sînâ' da ele alınma şekli için bk. İbn Sînâ, "el-lilahiyat", Kitâbu'ş-Şîfâ, s. 217 vd.

14 Ebu Nasr Fârâbî, İhsâu'l-Ulûm/İlimlerin Sayımı, çev.: Ahmet Ateş, Milli Eğitim Bakanlığı, İstanbul 1990, ss. 78-79; İbrahim Medkur, "Fârâbî”", İslam Düşünce Tarihi içinde, c. 2, s. 72; Günaltay, “İbn Sînâ ve Mantık”, s. 2; Durusoy, Metinlerle Mantığa Giriş, ss. 167, 324-327; a.mlf., "İbn Sînâ'nın Klasik Mantığa Katkıları”, ss. 183-184. 
$\mathrm{Bu}$ bağlamda düşünce arasında tümel/evrensel düşünce ile bunun bölgesel/yerel/tikel ifade tarzı olan dil arasında sıkı bir ilişki vardır çünkü dil, düşüncenin kılıfıdır. Bu çerçevede mantığın konusu olan tek bir akıl ve düşünce ve bunlara dair yasalar bütün insanlarda bir ve aynıdır denilence yeryüzünde birçok farklı dil ve bunların her birinin kendine özgü ilkeleri var, bu durumda ne olacak, sorusu mantığın çözmesi gereken önemli bir nokta olarak ortaya çıkar. Çünkü mantıklı düşünmede, fikirlerden yapılan hükümlerden çıkarılan sonuçların da tutarlı olması gerekir, tutarlı düşünme ise akıl yürütmenin akıl ilkelerine (özdeşlik, çelişmezlik, üçüncü halin imkânsızlığı) uygun olması demektir. İnsanlar, bu ilkelere uygun olarak düşünür, akıl yürütür ve kanıtlamalarda bulunur.

Formel veya genel mantık denilen bu tarz anlayışta konular dikkate alınmaz, sadece zihin ile akıl ilkeleri arasındaki uygunluk araştırılır. Aristoteles'in “Organon" ismiyle ortaya koyduğu mantık budur. Bir de özel, yani metodoloji anlamında kullanılan mantık vardır; düşüncelerin, zihne uygunluğunun yanı sıra konulara yani gerçeğe uygun olup olmadıklarını araştırır. ${ }^{15} \mathrm{Bu}$ özellik, yöntem olarak Mantık'a tekabül eder. Bilim olarak mantık, yöntem olarak Mantığın bilimi, yani aklı yürütmelerin doğruluğunu/düzgünlüğünü sağlayan kuralları ortaya koyan yöntem bilimin adıdır. Bu yöntem bilim dalına meta-mantık (metalojik) denir. Akıl yürütme, öncüller/yargılar arasında bir bağ kurarak sonuç da bir yargı çıkarmak demek olup bilinenden bilinmeyene ulaşmayı hedefler. ${ }^{16}$

Geleneksel mantık ile fenomolojik görüş açısında mantık arasındaki nüansta bu noktada belirir. Klasik mantık, kendisini kavramların, yargıların ve yarg1lardan çıkarılan sonuçların bir bilimi olarak görürken fenomolojik görüşte mantık, düşünceler arasındaki bağ ve düzeni “yöneten" ilkeleri araştıran bir bilimdir. Bu ilkelerin hedefi içkin/immanent bir hakikati yani doğruluğu gerçekleştirmektir. Doğruluk ile özdeşlik, çelişmezlik, üçüncü halin imkânsızlığı ilkelerine uygunluk kastedilir. Burada doğruluk, özne ile nesne arasında bağ kuran

15 İbn Sînâ, Medhal, ss. 12-14; Arslan, age, ss. 52-54-58-59; Necati Öner, Klasik Mantık, Ankara Üniversitesi İlahiyat Fakültesi Yay., Ankara 1991, ss. 1-3; Takiyettin Mengüşoğlu, Felsefeye Giriş, Remzi Yay., İstanbul 1983, ss. 106-108; İsmail Köz, Mantık Felsefesi, Elis Yay., Ankara 2003, ss. 20-21; Yaren, age, s. 10; Grünberg, Felsefe ve Felsefi Mantık Yazıları, ss. 366-368.

16 Bu çerçevede, Mantık bir ilim mi, yoksa bir alet mi tartışmasını İbn Sînâ, faydalı bulmaz, zira hem yanlış hem de gereksizdir. Her durumda mantık, hem felsefenin bir parçası hem de felsefenin diğer parçaları için bir alettir. Bk. Medhal, ss. 8-9; Günaltay, "İbn Sînâ ve Mantık", ss. 1-2; Durusoy, "İbn Sînâ'nın Klasik Mantı̆̆a Katkıları”, s. 190; Grünberg, Felsefe ve Felsefi Mantık, ss. 367-368; Arslan, age, ss. 51-63. 
aktların öznedeki uçlarıyla nesnedeki uçlarının birbirine uygun gelmesi demek olan aşkın/transendent hakikatin ilk şartıdır. Aşkın bir hakikat için doğruluk gerekli bir şarttır ama yeterli bir şart değildir. ${ }^{17}$

Bunun için “öncelikle bilinenden bilinmeyeni nasıl elde edeceğini, bilinenlerin, bilinmeyenin bilgisini vermeleri için insanın kendinde düzenlenişin nasıl olacağını bilmesi gerekir." Bilgi ve benzeri konularda araştırmalarımızın tama$\mathrm{m}$, elde edilmek istenen bir kavrama veya yargıya yöneliktir. Bu yargıyı verene kanıt-hüccet denilmekte olup üç tür akıl yürütme ile elde edilir. Bunlar tümevarım/istikra, tümdengelim/kıyas ve temsil/analojidir. ${ }^{18}$

Meşşâi filozofların ilk muallim kabul ettikleri Aristoteles'e göre tümelden tikele giden işlem olan tümdengelim, doğa açısından daha açık ve akli; tikelden tümele giden istikra ise bizim için daha açık, daha ikna edici, duyusal bakımdan daha anlaşılır ve daha popülerdir. ${ }^{19}$ Klasik mantığın en çok önem verdiğ $i$ ise bunlardan tümdengelimdir zira öncülleri dile getiren önermelerde sonuç zorunlu bir şekilde çıkarılırsa bu çıkarım geçerli/doğru demektir. Diğer bir ifadeyle eğer önermenin yalın biçimi/formu öncüllerden sonuç çıkarmayı garanti ediyorsa çıkarsanabilir ve geçerli önerme denir. Bu çıkarımda kanıtın öncüllerini doğru saydıktan sonra sonucunu yanlış kabul etmek imkânsız olmalıdır. Bu nedenle olsa gerek "Mantık, çıarsanabilirlik öğretisidir" denilmektedir. Bu tümdengelimde gerçekleşir. Sonucu öncüllerden ihtimalli olarak çıkan akıl yürütmeler ise ilk akıl yürütme gibi "geçerlilik" vermez. Bunlara da tümevarımsal akıl yürütme denir. Bu açıdan o, mantıksal sonuca benzer ancak ondan daha zayıf bir destekleme kavramı geliştirmeye çalışan mantık türü olarak nitelendirilir. ${ }^{20}$ Hatta öncüllerin doğruluğu bilinen tümevarımlı bir çıkarımın sonucunun doğruluğuna belli bir ihtimalle de dahi güvenilmez, hükmünden hareketle bu

17 Mengüşoğlu, age, s. 10; Aşkınlık hususunu Kant'tan öne mantığın konusu yapan İbn Sînâ'dır. Eşyanın mahiyetinin bir zihinde bir de dış dünyadaki varlıkları olduğunu belirten İbn Sînâ, mantığın konusunun mahiyetin zihindeki bulunuşu sırasında ortaya çıktığını söyler. İbn Sînâ, Mantıku'l-Meşrikiyyin, s. 30; Buna dair müzakere için bk. Durusoy, İbn Sînâ, ss. 182-183.

18 İbn Sînâ, Medhal, ss. 10-11; İşaretler ve Tembihler, ss. 2-4, 50; Durusoy, “İbn Sînâ'nın Klasik Mantığa Katkıları", s. 185.

19 Aristoteles, Organon III: Birinci Analitikler, çev.: H. Ragıp Atademir, Milli Eğitim Bakanlığı, İstanbul 1996, ss. 132-134; Organon IV: İkinci Analitikler, Milli Eğitim Bakanlığı, İstanbul 1996, ss. 3, 136; Nikomakhos'a Etik, çev.: Saffet Babür, Ankara 1997, ss. 12: 1098b; Arslan, age, s. 94.

20 Öner, age, ss. 3-4,104; Teo Grunberg, "Mantık ve Gerçeklik”, Türkiye I. Felsefe Mantık Bilim Tarihi Sempozyumu Bildirileri, Ankara 1991, ss. 231-232; Albert Mene, Mantığa Giriş, çev.: Lokman Çilingir, Elis Yay., Ankara 2005, ss. 9-10; Teo ve David Grunberg, Adnan Onart, Halil Turan, Mantık Terimleri Sözlüğ̈̈, METU, Ankara, 2003, ss. 133, 138; Mcginnis, agm, s. 307. 
ihtimalliğin nesnel değil, öznel olup her türlü akılcı dayanaktan yoksun bir alışkanlıktan kaynaklandığı belirtilerek tümevarımlı akıl yürütmeleri mantığın alanı dışına itenler de vardır. ${ }^{21}$

Görüldüğü üzere her halükarda "mantık, ilimlerin tamamını anlayabilmek için en iyi yardımcıdır. Bunu anlayamayanlar cehalet eseri mantığa düşmanlık gösteriyorlar, faydalarını inkâr ediyorlar." Oysa mantık bütün ilimlere bir giriş ve hazırlıktır. Başka bir ifadeyle "herkesin herhangi bir özel bilimle uğraşmaya başlamadan önce alması gereken genel kültürün bir parçasıdır"22 Bu nedenle olsa gerek İslam düşüncesinde de "Mantık bilmeyenin ilmine güven olmaz" denilmiştir. ${ }^{23}$

\subsection{Bir Akılyürütme Tarzı Olarak Tümevarım}

Tümevarım, Sokrates'den bu yana epistemoloji ile uğraşan filozofların sistemlerinde zihnin gerçeği bulmak için kullandığı yöntemlerden biridir zira zihin tekil varlıklardan hareketle tümevarımla genel fikirlere ulaşmak ister. ${ }^{24}$ Tümevarım, özellikle matematik disiplininde sayılar kuramında yeri ayrıdır. "Sonsuz çıkış ve sonsuz iniş" şeklinde ifade edilen bu yöntemde her yaştan insanı cezp edecek bir nokta bulunur. ${ }^{25}$ Bu noktada tümevarım meselesi, gerek felsefe ve bilim tarihinde gerekse bilimin doğa ve yönteminin sistematik ve mantıksal tahliller ile uğraşan disiplinlerde önemli bir yer tutar. Çünkü özellikle bilim adamlarının gözlem ve deneylere dayanarak yeni varsayımları benimsemeleri sürecini ifade eder. ${ }^{26}$ Francis Bacon'un bu yöntemin geliştirilmesindeki rolü çok büyüktür Bir anlamda o, deneysel felsefenin/bilimin kurucusu, yeniçağ pozitivizminin babasıdır. Bu nedenle tabiat hakkında ileri sürülen her soyut fikre

21 Grünberg, Felsefe ve Felsefi Mantık, ss. 368, 378.

22 Arslan, age, s. 52; krş. Emiroğlu İbrahim, Klasik Mantığa Giriş, Elis yayınevi, Ankara 2004, s. 21 $\mathrm{vd}$

23 El-Gazzali, el-Mustasfa min ilmi'l-Usul, Daru İhya'il-Turasi'l-Arab, Beyrut, ts., s. 10; krş. Günaltay, agm, s. 3; Yaren, age, s. 12; Emiroğlu, age, ss. 43-49

24 Yaren, age, s. 36.

25 "Burada kanıtlanmak istenen önerme önce 1 için kanıtlanır, sonra önermenin $n$ için geçerli olduğu varsayılarak $n+1$ için kanıtlanır. Böylece önermenin tüm sayılar için geçerli olduğu söylenir. Çünkü önerme 1 için doğrudur, 1 için doğru olduğundan 2 içinde doğrudur." şeklinde devam ettiğinden dolayı bu yönteme sonsuz çıkış da denilebilir. Bk. Ali Nesin. age, ss. 4950 .

26 Jules Lachelier, Tümevarımın Temeli Hakkında, çev.: H. Ragıp Atademir, İstanbul 1986; s. 4; krş. Russel, age, s. 31; Grunberg, Onart, Turan, Mantık Terimleri Sözlüğ̈̈, s. 138. 
yani bilimlerden ayrı her metafiziğe karşı büyük bir hıncı vardır. Düşünce tarihinin en büyük filozofu sayılan Aristoteles de bundan payını alır. ${ }^{27}$

Yeniçăg ile birlikte artık dış dünyanın/doğanın bilgisine, şeylerin mahiyetine ulaşmak amaç olarak görülmeye başlandı. Bilimin temel görevi, Newton'dan itibaren artık tanımlayıcı olan doğal yasalarım bulmaktır. Fakat bilim adamlarının bu yolda nasıl hareket etmeleri gerektiğini, sistemli bir şekilde ilk önce Francis Bacon anlatmıştır. ${ }^{28}$ Bacon'a göre bilimin amacı, insanın yeryüzündeki kaderini düzeltmektir. Artık bunun sırrını kitaplardan, okul'a hakim olan otoritelerden, önceden edinilmiş fikirlere ve apriori düşüncelere (idol) sormaktan vazgeçmek gerekir, düşüncesi hakim olmaya başladı. O kadar ki heveslerimizin, tercihlerimizin, önyargılarımızın tabiata zorla kabul ettirildiği belirtilmekte ve bunların terkinin ancak tümevarım yöntemiyle yani olgular ile organize edilmiş gözlemler toplanarak bunlardan teoriler türetilerek olacağ 1 söylenildi. Bunun için olsa gerek tümevarımsal çıkarımın deneysel bilimler için önemini vurgulamak Bacon'un felsefe tarihindeki değerini oluşturur da denilebilir. ${ }^{29}$ Tümevarımsal çıkarımlarda ihtimallikten bahsedildiği zaman bizatihi nesnellik değil de öznellik olduğu sorunu göz ardı edilerek, eğer böyle yapılmazsa bilim ile din birbirine karışır, bu karışımdan da hurafeye inanan bir felsefe ve Rafızîliklerle dolu bir ilahiyat çıkacağı vurgusu yapılır. "30 "Bilgi güçtür" diyen Bacon, bilmenin hâkim olmak demek olduğunu, bilimin amacının da tabiata hâkim olmak olduğunu belirtir. Nesnel bir doğa bilgisi elde etmek için öncelikle zihnin önyargılardan temizlenmesi gerektiğini söyler.

Onun tümevarım yönteminde iki aşama vardır, ilkinde ele alınan incelenen tikellerin olduğu varlar/bulunanlar listesi, incelenemeyenlerin yer aldığı yoklar listesi ve bu ikisi arasındaki mukayeselerin/çıkarımların yapıldığı, göründüğü hallerin dereceler listesi yapılır. Burada bulunacak olan, incelenen olgu ile görünen ve görünmeyen, onunla birlikte çoğalan ile azalan özelliklerdir. Daha sonra yönteminin ikinci aşaması olan ayıklama gelir. Bu husus önemli, çünkü açıklanan özelliğin bulunduğu hallerde rastlanmayan bütün özellikleri dışarıda bırakmak, kişiyi aceleci ve temelsiz genellemeler yapmaktan kurtarır. Bu şekilde

27 Alfred Weber, Felsefe Tarihi, çev.: H. Vehbi Eralp, Sosyal Yay., İstanbul 1998, s. 209; Alan Chalmers, "Bilim Dedikleri", Bilimin Doğası, Statüsü ve Yöntemleri Üzerine Bir Değerlendirme, çev.: H. Arslan, Vadi Yay., Ankara 1994, s. 31.

28 Magee, age, s. 17; Chalmers, age, s. 27.

29 Reichenbach, Bilimsel Felsefenin Doğuşu, s. 62.

30 Weber, age, ss. 207-208. 
bir dışarıda bırakma gerçek tümevarımın temelidir, zira daha önce olumlu yönler sayılırken burada olumsuzun da göz önünde bulundurulması vardır. Ama amaç yine de olumluyu/doğruyu bulmaktır. Dolayısıyla tümevarımda asıl sorun, doğrulanabilirliktir. Olumlu özellikleri bulmak kesin doğruyu bulmak demek değildir, bilakis ilk aşamadır, ek çarelere de gerek vardır. Bunlara dikkat edildiği takdirde yaygın şekilde savunulan bilim görüşü ortaya çıkar.

Buna göre "bilimsel bilgi doğrulanmış bilgidir. Bilimsel teoriler bir kısım titiz yöntemlerle gözlem ve deneyle elde edilen deney olgularından çıarılırlar. Bilim görebildiğimiz, işitebildiğimiz, dokunabildiğimiz şeyler üzerine bina edilir. Bilimde şahsi fikirlerin veya tercihlerin ve spekülatif tasavvurların yeri yoktur. Bilim nesneldir, bilimsel bilgi de nesnel olarak doğrulandığ için güvenilir bilgidir." 31 Gökberk'e göre Bacon, tümevarım ile nesnelerin mahiyetini bilmek ister ama bu modern anlamda tümevarım anlayışına uymaz zira burada bir olayın başka bir olay ile olan bağlılığı gösterilmez, bir yasa ortaya konmaz, yalnız bir kavram ortaya konur. Bununla birlikte düşünce tarihinde yeni bilgilere ulaşmayı hedefleyen araştırma mantığının öncülerinde olması, metafiziksel kurgular yerine olguları çıkış noktası yaparak tümel önermelere ulaşmaya çalışması açısından önemlidir. ${ }^{32}$

Lachelier'e göre zaten tümevarım iki türlüdür, ilki bilimsel olanıdır. Burada iyi tespit olmuş tek bir olguyu kanun haline konulması söz konudur çünkü her olgu, bir kanunun ifadesidir. İkincisi ise Bacon'un eleştirilere uğrayan tümevarımıdır. Örneklerin basit bir sayımı ile başlar ve kendinden önce hiç bir şey farz etme yoktur dolayısıyla da birinci ilkenin doğru olduğunu göstermeye yarayan ilkeye pekâlâ temel vazifesi görebilendir. Bu terk edilmiştir zira tabiatın özel kanunları söz konusu olduğu zaman tam bir sayımın olması mümkün olmadığı için hiç bir güvene layık değildir. ${ }^{33}$

Popper açısından ise Bacon'un uzun süre etkisini sürdürmüş olan anlay1şında bilim adamı varsayımını desteleyen deliller bularak doğrulamayı başarırsa doğanın gizlerini daha da açacak bir başka bilim yasası bulmuş demektir:

“Genel önermeleri özgül durumların biriktirilmiş gözlemlerine dayandırma

31 Chalmers, age, s. 31.

32 Gökberk, age, ss. 244-245; Modern tümevarımcılar, bir teorinin ilk düşünüldüğü ve keşfedildiği şekliyle, doğrulandığı veya yararlarının belirlendiği şekli arasında bir ayırım yaparak bilimin tarafsız ve önyargısız gözlemle başlaması gerektiği tezinden vazgeçerler. Bk. Chalmers, age, s. 79 .

33 Bununla evrensel nedenlik kanununu karıştırmamak gerekir. Bk. Lachelier, age, s. 17. 
yöntemi olan tümevarım, bilim ile bilim olmayan arasındaki sınır çizginin ayracı sayılır. Bilimsel önermeler, gözlemsel ve deneysel delillere/olgulara dayanmakla ister otoriteye ister duyguya, geleneğe, kurguya, önyargıya, alışkanlığa ister başka herhangi bir temele dayanan bütün öteki türlerdeki önermelerden kesin ve güvenilir bilgiyi (bir onlar ) sağlamakla ayrılırlar. Bilim işte böyle bilgilerin toplamıdır, bilimin büyümesi de varolan kesinliklere yenileri ekleme yolundaki sonsuz süreçten oluşur." 34

Bu çerçevede İbn Sînâ'nın bilimsel araştırmanın bir vasıtası olarak gözlem ve deneyimi (tecrübe) bir yöntem olarak geliştirmeye çalıştı̆̆ını hatırlamak gerekir. Üstelik bunu mutlak ilkeler vermeyeceğini söyleyerek yapması önemlidir; tabiat bilimcisi gözlem ve deneyimi arizi şartların keşfi için kullanabileceğini, bilimde ilk ilkeleri olarak işlevsel olanın tümel, evrensel ilkeler olduğunun bilinciyle yapar. Başka bir ifadeyle "duyu deneyimlerimize dayanarak oluşturduğumuz gözlem önermeleri bilim için sarsılmaz bir temel oluşturur. İlk aşamada âlim, olayları hiçbir önyargıya kapılmadan nesnel bir biçimde gözler, sınıflandırır sonra da tümevarımla genel hipotezlere ya da bir kurama varır. İkinci aşamada ise bu teori sınanır. Bunun için teoriden tümdengelim yoluyla öndeyiler türetilir. Öndeyiler gerçekleşirse kuram desteklenmiş, belgelenmiş; aksi halde yanlışlanmış sayılır." 35 Bu son cümleden dolayı olsa gerek, tümevarımlı kanıtlamanın temelde tümdengelimin bir biçimi olduğunu ve temel mantıklı sayı kuramını gözden kaçırmamak gerekir diyenlere de dikkat etmek gerekir. ${ }^{36}$

Bilim adamının görevi de önermeler ortaya koymak ve bunları sistemli bir şekilde sınamaktır. Emprik bilimlerin tanımı de genel olarak tümevarım yöntemi ile tanımlanır. Gözlem ve deneyleri tanımlayan özel önermelerden evrensel önermelere yani varsayımlara ve kuramlara ulaşma anlaşılmaktadır. Bu açıdan tümevarım, bir yandan bir keşif yöntemi olarak genel bir kurama varmamızı temin etmekte diğer yandan ise kurama tümevarımsal bir argümanla destek vererek onu belgelemekte ve temellendirmektedir. Bunun ilk kısmına, bir keşif yöntemi olarak ele aldığına psikolojik tümevarım, ikincisine yani belge-

34 Magee, age, ss. 17-18.

35 Irzık, agm, ss. 21-24; Bilim adamının önyargısız bir şekilde incelediği konuya yaklaşması, kişisel inanç ve eğilimlerini bir tarafa bırakması mümkün değildir, önyargısızlık temelde bir önyargıdır, şeklindeki Popper'in eleştirisi için bk. Aynı makale, s. 28.

36 Temel mantıklı sayı kuramından kasıt, doğal sayıların toplamı ile çarpımına ilişkin kanıt savları türetmeye yarayan temel mantıklı kuramdır. Bk. Grunberg, Onart, Turan, Mantık Terimleri Sözlü̈̆̈̈, ss. 128, 138. 
leme anlamındakine ise mantıksal tümevarım adını verir. ${ }^{37}$

Bu bağlamda Lachelier "tümevarım, bizi olguların bilgisinden bu olguları da idare eden kanunlara giden işlem" diye tanımlar ve bu işlemin mümkün oluşundan kimsenin şüphe etmemesi gerektiğini belirtir. ${ }^{38}$ Fakat bu husus, gerek epistemoloji gerekse mantık ve metodoloji açısından henüz çözülmemiş ve türlü açıklamalara yol açan en çetrefil bir konu olarak kalmaktadır. Bu hususu araştırmadan önce tümevarımsal akıl yürütmelerin mahiyeti üzerinde biraz durmak gerekir. Çünkü Richard Swinburne göre bazen öncüller sonuca tümdengelimde olduğu derecede kesinlik kazandırmaz ama öncüller sonucu bir anlamda "destekler", "pekiştirir" veya "takviye eder". Dolayısıyla iki farklı ispatlamanın arasını ayırmak gerekir. Bu tür ispatlamaların bazısı veya tümü genellikle "iyi", doğru" veya "güçlü tümevarımlı kanıtlar olarak değerlendirilebilir. ${ }^{39}$

Burada tümdengelim ile ilgili bir hususu belirtecek olursak 1 ve 2. Öncüller doğru sayıldığı için sonuç (3.öncül) yanlış olamaz ama 1. öncülde yapılacak ufak bir değişiklik sonucun yanlış olma ihtimalini ortaya çıkarabilir. Örneğin, 1 . öncül: Felsefe ile ilgili birçok kitap can sıkıdır. 2. Öncül: Bu kitap felsefe ile ilgili bir kitaptır. 3. öncül/sonuç: Bu kitap can sıkıcıdır.

Burada sonucun yanlış olması mümkündür, zira can sıkıcı olmayan felsefe kitapları da vardır ve elinizdeki kitap bunlardan biri olabilir. Fakat burada (1) ve (2)nin doğru, (3)ün yanlış olduğunu öne sürmede bir çelişki yoktur, argüman geçersizdir. Çünkü orta terimin (felsefeyle ilgili kitap) yerini dikkate aldığımızda "Barbara" dır. Ancak büyük önermenin niteliğinden dolayı geçersizdir. Kısacası tümdengelimsel çıkarım, salt dünyayla ilgili bir doğru önermeler kaynağı olarak işlemez çünkü öncüllerin doğru olup olmadığı mantığa müracaat edilerek çözülecek bir sorun değildir. ${ }^{40}$

Bu tespit, tümevarımın özellikle işlevsel olduğu tabiat (ve beşeri) bilimlerde mantık'ın hiçbir yararı olmadığı anlamına gelir mi? Eğer sorun, gerçeklik (varolan somut ve soyut nesnelerin) bilgisini elde etmek ise bir yarg1 veya önermenin doğruluğunun güvenilir ve yeterli gerekçeler, belgeler/delillere da-

37 Fakat Popper, her ikisini de reddeder. Bk. Popper, Bilimsel Araştırmanın Mantı̆̆ $ı$, s. 51; Irzık, agm, ss. 21-22.

38 Lachelier, age, s. 3.

39 Örnekler için bk. Richard Swinburne, "Tümevarımlı Kanıtlar" çev.: Turan Koç, Erciyes Üniversitesi Illahiyat Fakültesi Dergisi, Kayseri 1992, say1: 8, ss. 273-274, 290-291.

40 Chalmers, age, ss. 39-40. 
yanarak tespiti gerekir. Fakat tümevarımla ilgili olarak bir türün tek bir bireyden ibaret olması veya bir türün içine giren bütün bireylerin sayılmasının imkânsız olması olgusu ne olacaktır?

Bunun yanı sıra "Bir türün içine giren bireylerin sayısı sonlu veya sonsuz olsun gözlemlediğimiz değişmez veya tekrarlanan niteliklerinin onların özlerini, doğalarını oluşturduğunu nereden biliyoruz? Bununla kastettiğimiz, her zaman sinırlı sayıda olmak zorunda olan tekrarlanan deneyin bize bir varlık veya olayın mahiyetini sezdirmede kesin bilgi verecek yeterlilikte olmamasından başka bir şeydir. Bir sınıfa ait bütün üyeleri bir türe ait bütün bireyleri teker teker yoklasak bile gözlemlediğimiz tekrarlanan herhangi bir özelliğin, bu varl1ğın mahiyetini bize vermiş olduğu şeklinde sahip olacağımız kesinlik duygusunun kaynağı nedir? ${ }^{41}$ Dolayısıyla eğer maksat, insanın gerçekliğe erişmesiyse gerçeklik hakkında doğru/tutarlı bilgi edinmesi şarttır. Ama bu nasıl olacaktır? Bu nedenle olsa gerek, bütün meseleler, hassaten felsefî olanlar, son tahlilde bir mantık meselesine indirgenebilir, denilebilir. ${ }^{42}$ Bu husus, özellikle tabiat bilimlerinde çeşitli deney ve gözlem verilerinden hareketle tabiat yasalarının ne olduğu konusunda bir sonuca varmaya çalışan tipik bilimsel kanıtta öncüllerin sonucu ihtimal dâhiline mi soktuğu yoksa ihtimaliyetine sadece katkıda mı bulunduğu sorusu da bu bağlamda önem kazanmaktadır. Yine deney ve gözlemin tüm zamanlarda yapılamaması gibi bir mesele de vardır.

İşte sorun da buradadır. Mantık biliminde tümel-tikel ilişkisini tartışmak doğaldır ama görüldüğü üzere bunu diğer felsefî branşlar açısından değerlendirmek için aynı şeyi söylemek mümkün değil. Bunu Magee'nin ifadesiyle “tümevarım, insan bilgisinin temelinde çözülmemiş bir sorun olarak kalmıştır, çözülünceye kadar da tüm bilimin içsel olarak ne kadar tutarlı, dışsal olarak da ne kadar faydalı olursa olsun ayağını sağlam olarak toprağa basmadan havalarda uçuşan bir şey olduğu" itiraf edilmelidir.43

Tümevarım gerçekten bir sorundur, zira Aristoteles'ten bu yana kullanılan bu yöntem üzerine çok ciddi eleştireler getirilmiştir. ${ }^{44} \mathrm{Bu}$ da doğaldır, çünkü

41 Arslan, age, s. 97.

42 Russel, age, s. 30.

43 Magee, age, s. 20; krş. Necip Taylan, Mantık, Marmara Üniversitesi İlahiyat Fakültesi Vakfı Yay., İstanbul 1996, s. 147.

44 Tümevarım, Aristoteles'e göre daha başladığında yani Sokrates ile birlikte tükenmiştir. Çünkü Sokrates' in yöntemini yani örneklerden yola çıkarak bir şeyler öğrenmeye, Aristoteles gibi biz de tümevarım dersek şu husus eklenmelidir. Sokrat, ispatlamalarından en önemli örnekleri karşı örnekler olup yargıya ulaşmada Aristoteles' in tümevarımından çok farklıdır. Sokra- 
mantıksal açıdan bu kadar çok tikelden (özel önermelerden) tümele (evrensel önermelere) eksiksiz ve tam olarak ulaşılması imkânsızdır. Bu aslında tam sayımlı tümevarım, yani tümelliği konusunda genel bir sonuca ulaşmadan önce bir tümelin bütün özel hallerinin teker teker incelenmesidir. Bu özel halleri bir türün içine giren bireyler olarak değil bir cinsin kaplamını meydana getiren türler olarak ele alır. Bunun yanı sıra tümevarımı Aristoteles, bazı yerlerde ise sonucu yalnızca bir veya iki örneğe dayandırdığı da gözlemlenir. ${ }^{45}$ Bizim incelediğimiz bu tür çıkarımdır. Tümevarım yönteminin niçin bir sorun olmaktan kurtulamadığı hususunu merkeze aldığımız için “biz doğrudan doğruya olguları biliyoruz ve bu olgulardan, içerdikleri evrensel hakikatleri çıkarmak için elimizde bulunan biricik araç tümevarımdır" şeklindeki mutlak savunusuna yönelik Jules Lachelier' in ifadesini ${ }^{46}$ hatırladığımızda sorunun boyutu daha iyi anlaşılmaktadır.

“Tümevarımın işleyişinden hiç şüphe etmeyen Lachelier, "her yerde ve her zamanda uygulanabilen bir kanun koymak için belirli bir zamanda ve yerde gözlemlenen bazı olguların bize yetmeleri niçin tuhaf geliyor?" sorusunu sorar. Cevap olarak da "En iyi yapılan deney, olguların gözlerimiz önünde birbirine nasıl bağlandıklarını bize dosdoğru öğretmekten başka bir şeye yaramaz. Fakat her zaman ve her yerde aynı tarzda bağlanmak zorunda olmaları, işte bize öğretmediği şey budur, bununla birebir tasdik etmekte tereddüt etmediğimiz de budur."der. ${ }^{47}$

\subsection{Tabiat Bilimlerinde Tümevarım Yönteminin Kullanımı}

Bu noktada bilim ile bilim olmayan arasındaki sınır çizgisinin ayracı olarak tümevarım yönteminin kullanımı meselesi gündeme gelir. Bu, sonraları “Hume sorunu" diye nitelendirildiği üzere tümevarımda bir sınırlandırma ayracına sahip olamamak gibi bir durumu ortaya çıkarmıştır. Zira tümel, bir önermede, bir sınıfın üyeleri için eksiksiz ve istisnasız olan bir yüklem olmayı ifade eder.

tes'in ispatlamaları, kendini yanlışlama, yani karşıt örnekler getirerek çürütme, karşıt dayanakları, doğmaları çökertme biçimindedir. Bu çürütme yöntemi eleştirel akılcılık olup Sokrates ile birlikte zirveye ulaşmıştır. Aslında onun hiç bir şey bilmediğini söylerken güvenilir bir bilgiye sahip olamayacağımızı vurguladığını belirtilir. Popper, Bilimsel Araştırmanın Mantı̆̆ı, ss. 592-593.

45 Arslan, age, ss. 94, 98.

46 Lachelier, age, s. 16.

47 Aynu eser, s. 3. 
Böyle bir tümele, sınırlı sayıdaki deneyimlerle tek-olanların gözlemlenmesi yoluyla ulaşılamaz. ${ }^{48}$ Bu nedenle olsa gerek deneyle elde edilen bilgi, özelikle de bilimsel bilgi, kavram halinde ifade edildiğinde genel değil genelleştirilmiş bilgidir. Kısacası tümel, hiç bir şekilde tekillerden hareketle kendisine ulaşılabilecek bir şey değildir. O ancak zihinsel olarak tasarımına sahip olduğumuz bir fikir/ideden ibarettir. ${ }^{49}$

Bu tespit, bizi daha ilginç bir noktaya; bilim ve yöntemlerinde özel bir şey bulunduğu yaygın şekilde kabul gören bir inanç olduğunu söylemeyi mümkün kılmaya getirir. Dolayısıyla "Bilimsel" nitelemesi de bir tür geçerlilik veya özel türde bir güvenilirlik ima etmesi istenildiği için verilmiştir, denilebilir. İlginç olan husus, bu tanımın bilime yönelik sübjektivist yaklaşımda bulunanlara ait olmasıdır. Popper, mantıkçı pozitivistler ile öteki tümevarımcıların sübjektivistler diye adlandırdığ 1 felsefeciler sınıfına ait olduğunu söyler. Üstelik rasyonalist Descartes ile empirist Locke ve Berkley ile tümevarıma ciddi eleştiriler yönelten Hume'u da bu kategoriye dâhil eder. ${ }^{50}$

Bilim/fizik ile bilim olmayan/metafizik hususların ayracı olarak tümevarım kullanılması gerektiği düşüncesi çok ciddi eleştirilere uğramıştır; bu yönteme uygun bir sinırlandırma ayracına rastlanılmamaktadır. Bundan kasıt, teorik bir önermenin metafizik olmayan emprik özelliklerini bile görmenin zor olmasıdır. David Hume'un (1711-1776) çözmeye çalıştığı sorun da budur yani görgül/emprik bilimlerin hem matematik ve mantık hem de metafizik önermelerden ayıran ölçütlerin bulunmasına çalışır. ${ }^{51}$

\subsection{Tümevarıma Yöneltilen Eleștiriler}

Manevî/beşerî bilimlerin insanlar arasında sürekli tartışma ve ayrışma konusu olduğuna dikkat eden Hume, herkes tarafından kabul gören sonuçlar üretil-

48 Lachelier, bunu ayrıntılı bir şekilde tartışır ve olguların bilgisinden kanunların bilgisine geçmenin mümkün olduğunu, üstelik bunun bir kuruntu değil de, gerçek bir tabiat bilgisine götüreceğini belirtir. Bk. Lachelier, age, ss. 3-14.

49 Özlem, age, s. 54; Bilginin özünün genelleme olduğunu söyleyen Reichenbach'ın bu bilginin çevremizdeki nesneleri denetleyip sömürmek için gerekli olduğunu söylemesi oldukça ilginç ve önemli bir husustur. Bk. Reichenbach, age, s. 14.

50 Chalmers, age, s.. 23, 179-182.

51 Bu sorun, daha sonra Kant tarafından epistemolojinin merkezi haline getirilmiştir. Bk. Popper, Bilimsel Araştırmanın Mantığı, s. 68, Reichenbach, gözlem ve deney üzerine kurulu emprizmin Bacon'a peygamberini, Locke'da liderini, Hume'da ise eleştirmecisini bulmadığını söylemesi bu bağlamda anlam kazanmaktadır. Reichenbach, age, s. 63. 
memesinin nedenini, bu ilimlerin konusunun tespit edilememesi ve bu konuları inceleyecek uygun bir yöntemin bulunmayışı olarak görür. Dolayısıyla sorun, bir yöntemsizlikten kaynaklanmaktadır. Ona göre "insan ilmi, öteki ilimlerin nasıl tek sağlam temeliyse bunun gibi bu ilme verebileceğimiz tek sağlam temel de ister istemez deney ve gözleme dayanmalıdır." ${ }^{22}$ Kısacası "tabii felsefe" sadece olguların gözlem ve incelenmesinden hareketle kurulacaksa bu takdirde insan zihninin/doğasının özellikleri ve içinde bulunduğu durumları ile bunlardan doğan sonuçların gözlemlenmesi de gereklidir. Bu da fikirlerimizin kaynağının araştırılması demektir. Çünkü son tahlilde bütün bilimlerin insan doğası ile irtibatı vardır, (matematik, doğal felsefe, hatta doğal din bile insanın bilişine bağlıdır ve bilgisel güç ve yetileri tarafından yargılanırlar. ${ }^{53}$

İlmin konusu, artık tecrübede verilmiş bulunan şey, yani gözleme tabi tutulacak olan şeye indirgenmiştir. Bu, salt olayları incelemek, bunun dışında kalan metafiziksel hususları konu dışı bırakmak demektir. Bu çerçevede bilginin elde edilme sürecini tahlil eder. ${ }^{54}$ Biz bunun aşamalara girmeden konumuz olan tümevarım yöntemi ile ilgili düşüncelerine geçmek istiyoruz. Tümevarım sorununa gösterilebilecek eleştirilerden en köklüsü David Hume'nun şüpheci tepkisidir. Felsefe tarihinde filozofların cevaplarından ziyade soruların önemli olduğu hususundan hareketle Hume' nun öneminin de tümevarımın mantıksal dayanağına ilişkin soruyu tartışması ve çözümün güçlüklerini belirtmesi olduğunu söyleyebiliriz. ${ }^{55}$

Hume'un sorunu, epistemolojik olarak olayları birbirlerine zorunlu olarak bağl1 imiş gibi nasıl gözüktügüüür? Gerçekten de zorunluluk düşüncesi nedir? Buna dair birkaç temel tespit yapmak gerekir. Ona göre insan zihnin bilgi edinme kaynakları izlenim ve düşüncedir. Dolayısıyla izlenimden edinmeyen hiç bir düşüncemiz olamayacağı için zorunluluk düşüncesini ortaya çıkaracak izlenimi aramak gerekir. Duyularımız tarafından iletilen ve zorunluluk düşüncesini ortaya çıkarabilen hiç bir izlenim yoktur. O halde o, belirli bir içsel izlenimden ya da derin düşünce (refleksiyon) izleniminden türetilmiş olmalıdır. Bir nesneden her zaman ona eşlik edenin düşüncesine geçmek için alışkanlığın

52 David Hume, İnsan Zihni Üzerine Bir Araştırma, çev.: Selmin Evrim, Milli Eğitim Bakanlığı, İstanbul 1986, (Levy Bruhl'un yazdığı önsöz, ss. VIII-IX), İnsan Doğası Üzerine Bir İnceleme, çev.: Aziz Yardımlı, İdea, Yay., İstanbul 1997, s. 41.

53 Hume, İnsan Zihni, s. 22 vd, krş. Bruhl, Önsöz, s. XII, İnsan Doğası, s. 40.

54 Hume, age, s. $45 \mathrm{vd}$.

55 Reichenbach, age, s. 68, Köz, age, s. 57 vd. 
ürettiği o yatkınlıktan başka, bu işle herhangi bir ilgisi olan hiç bir içsel izlenim yoktur. Dolayısıyla zorunluluğun özü de budur. ${ }^{56}$

Bu bağlamda kullanılan tümevarım, mantığa ve deneye dayanarak doğrulanamaz çünkü doğa yasaları ya da sebep-sonuç arasındaki ilişki denilen hususlar, mantıkla ilgili olmayıp duyularımızla ilgili alışkanlıklardır. Zorunlu bağlantı denilen şey, ne apriori ne de a posteriodirler, tersine, sadece deneylerden gelir. Deney de bize devamlı bir bağlantı bulunan özel nesneler gösterir. ${ }^{57}$ Üstelik bu bağlantı fikri bir sezgiden de meydana gelmemiştir çünkü zorunlu bir bağlantı olayların sadece görülmesiyle doğrudan doğruya kavranabilen bir şey değildir. ${ }^{58}$ Dolayısıyla geçerliliği hakkında şüphe her zaman vardır. Bu doğa yasalarını ret anlamına gelmez, diğer bir ifadeyle sebepsiz bir şeyin meydana geleceğini şeklinde saçma bir iddiada bulunmak demek değildir. Onun dediği, bir önermenin yanlışlı̆̆ üzerindeki güvenimiz, ne sezgiden ne de ispatlamaktan gelir. Örneğin yer çekimi gibi kanunları duyumsadığımız için atılan taş yere düşmez, biz, sürekli olarak atılan her taşın yere düştüğünü gözlemlediğimiz için bunu söyleriz. Gözlemlerimiz, bizlere bir sürekli beraberlik olduğunu söyler. Ama bu sürekli beraberlikten zorunlu bir bağlantı olduğunu iddiaya ve olumlanmasına geçmek mümkün değildir.

Kısacası Hume'a göre doğa yasaları veya teorilere duyulan inançlar, bizim uygun gözlemlerimizin tekrarının bir sonucu dediğimiz psikolojik alışkanlıklarımızdan başka bir şey değildir. Bu noktaya dikkat edilmezse hatalı sonuçlara varmak işten bile değildir. ${ }^{99}$ Çünkü ulaşılan sonuç birkaç tekil önerme/gözlemden çıkartılmaktadır, hâlbuki ne kadar "çok sayıda" gözlem yapılırsa yapılsın, sınırsız bir genel önermeye ulaşmak mantıken mümkün değildir ama psikolojik olarak gözlemlenen A olayı ile B olayının meydana gelmesinden hareketle bu söylenebilir. Fakat bu durum, "çok sayıda gözlem, çok değişik şartlar" ibarelerinin muğlâklığını ortadan kaldırmaz..$^{60}$

Bu noktada Popper de Hume gibi düşünür ve "gözlemlediğimiz olaylar-

56 Hume, Insan Doğası, ss. 100-103, 163-171; Stuart Mill'in çıkarımda bulunmak için illiyet/nedensel kanunu gerekir, sözüne karşı muhtemel cevapları tahlil için bk. Russel, age, ss. 31-32.

57 Hume, age, ss. 38-39, Bruhl, Önsöz, ss. XIX-XX; Sebep ve sonuç ilişkisinin nasıl olduğunu tespit etmemize yardım eden kurallar için bk. Hume, age, ss. 177-178, 106-107.

58 Hume, age, ss. 49-50.

59 Bk. Chalmers, age, s. 51-52, 58, Weber, age, s. 295; Gökberk, age, ss. 346-347.

60 Bk. Bruhl, Önsöz, s. XXI-XXIII. 
dan gözlemlemediğimiz olaylara geçmemizi sağlayacak bir çıarımın rasyonel bir temeli var mıdır? sorusuna o da "hayır" der. Tümevarımsal bir temellendirme fikri boş bir hayaldir ona göre de. ${ }^{61}$ Son tahlilde Hume, tümevarımsal çıkarımların geçerliliğin ispatın herhangi bir yolu yoktur ama psikolojik yapımız gereği onlarsız da düşünemeyiz çünkü uygulamada işler yapılmaktadır, der. Bunu demek ise bilimsel yasaların mantıksal, rasyonel ve deneysel temellerinin olmaması, dolayısıyla da kesin olmadıklarını söylemek demektir. Bununla birlikte bu her doğrulayıcı örnek, ihtimal derecesini yükseltmekte, bunun sonucu ise doğruya yakın ön deyilerde bulunmayı kolaylaştırmaktadır. Bu bağlamda bilimsel bilgiyi doğrulanmış bilgi değil de muhtemelen doğrulanmış bilgi şeklinde tanımlamak daha tutarlıdır. ${ }^{62}$

Hume sorunu, yani tümevarıma yönelttiği eleştirinin bizi empirizmden agnostizme (klasik bilinemezciliğe) götürmesi sorununu ${ }^{63}$ aşmak için Viyana Çevresi (neo pozitivist ve mantıksal görgücü) filozoflar da doğrulanabilirlik teriminden hareket etmektedirler. Bir önermenin anlamı, doğrulanabilirliğin şartları tarafından belirlenmekte, aksi takdirde anlamsız ve metafiziksel önerme diye nitelendirilmektedir. Çünkü bir önerme sadece mantıksal ve ampirik olarak doğrulanabilir olan önermedir, bu da ancak tekil gözlem ve deneylerden genele ulaşmakla mümkün olur. Bu hükümden çıkan sonuca göre bir önerme ancak gözlem ve deneye dayandırılarak doğrulanabilir. Dolayısıyla da temel önermelere dayandırılması mümkün olmayan bilimsel bir kuram kesinlikle yanlışlanamaz. Burada ki mantıksal doğrulamadan kasıt, önermenin mantık kurallarına uygunluğu, görgül (emprik) doğrulaması ise önermelerin mantıksal araçlarla gerçekleştirilmiş, tanımlayıcı biçimde açıklanmasını, bunun yolunun da dilsel çözümlemelerden geçtiğini söylemek demektir. ${ }^{64}$

\subsubsection{Tümevarım Sorununa Çözüm Önerisi Olarak "Yanlışlanabilirlik"}

Gerçekten de bilim adamı Bacon'un dediği tarzda ön yargılardan uzak bir şekilde evrendeki olguları tarafsız bir şekilde inceleyebilir mi? Ya da sonsuz say1da görünüme sahip bu olgulardan bazı görünümlerinden seçilerek elde edilen

61 Irzik, agm, s. 22.

62 Chalmers, age, ss. 52-55; Magee, age, ss. 18-26.

63 Reichenbach, age, s. 66.

64 Popper, age, s. 16; Hume' un eleştirisinde dile gelen emprizmin güçlüklerinin aslında bilginin yanlış yorumu olduğunu, dolayısıyla doğru bir yorumla bunun giderilebileceğinin ifadesi için bk. Reichenbach, age, s. 166. 
verilerin sistematize edilerek genelleştirilerek elde edilen bilimsel sonuç, salt bir olgular topluluğu mudur? Veya bilim, doğru ile özdeş midir? Gerçekten bu anlamda bir doğrulanma mümkün müdür? Yoksa evrende bir düzenin olduğu varsayımdan/öncülünden hareketle yani tümdengelimsel bir şekilde olgular incelenmektedir?

Karl Popper, bilimin bir koleksiyon olduğunu dolayısıyla da bilim adamının ilgilerine bakış açısına bağlı olduğunu belirterek bu soruya cevap verir. Dünya hakkındaki bilimsel teoriler, kişilerden bağımsız olgu kümeleri değil bizzat insan zihninin ürünleridir. Diğer bir ifadeyle ona göre "bilimde bu görüş açısı çoğu kez bir kuram tarafından belirlenir. Yani sonsuz sayıdaki olguların ve bu olguların sonsuz türlü görünümlerinin arasından az çok önceden tasarlanmış olan bir kuramla ilgili bulguları ve görünenleri seçeriz". ${ }^{65} \mathrm{Bu}$ noktada kuram, "önceki kuramlar tarafından karşılaşılan sorunların üstesinden gelinmek ve dünya ya da evrenin bazı görünümlerinin hareketinin yeterli bir açılamasını sağlamak üzere yapılan bir teşebbüsle insan zekâsı tarafından özgürce yaratılan teorik ve deney kabilinden varsayım veya tahminler" olarak yorumlanir. ${ }^{66}$

"Her buluş irrasyonel bir an içerir, her buluş yaratıcı bir sezgidir." Bergson'un bu sözünü Popper, çok önemsemiş, Hume'un tersine yasalara ulaşmanın yolunun mantık değil salt sezgiye dayanan deneyim özdeşleşimidir, demiştir. Ona göre tüm bilgi, tahmini bilgidir, farklı tahminler ya da varsayımlar da sezgisel buluşlar yani önsel bilgidir. Bunlar deneyimle ayıklanır ve yerine daha iyi tahminler yürütülerek yenileri aranır. İşte deneyimin bilimsel araştırmalara katkısı yalnızca budur. Bunun dışındaki her şey, araştırmaya yaklaşımımızla biçimlenir. Artık yapılacak tek şey, kuramlarımızın sınanabilir yargılarının aranmasıdır yani kuramlarının muhtemel yanlışlarını ortaya koymak için deneysel şartları oluşturmaktır. ${ }^{67}$

Dikkat edilirse Popper, bilimsel yöntem hakkındaki geleneksel görüşün gözlem ve deney, tümevarımsal genelleme, varsayım, varsayımın doğrulanması girişimi, doğruluk ya da yanlışlığın kanıtlanması ve bilgi şeklindeki kurgusunu reddetmiştir. Zira hiçbir yönlendirici varsayımda bulunmadan salt göz-

65 Karl R. Popper, Açık Toplum ve Düşmanlarl, çev.: Harun Rızatepe, c. 2, İstanbul 1994, s. 226; Magee, age, s. 27; Gözlem önermelerinin bir teoriyi gerektirdiği hususunda ayrıca bk. Chalmers, age, s. $69 \mathrm{vd}$.

66 Chalmers, age, s. 83.

67 Popper, Bilimsel Araştırmanın Mantı̆̆ı, ss. 17, 596. 
lemden yola çıkarak genel yasa ya da kuramların keşfedilebileceğini va'z eden psikolojik tümevarım mümkün değildir. Gözlem, daima bir kuram, daha doğru bir deyişle varsayıma bağımlıdır dolayısıyla elimizde bir kuram ya da varsayımın yol göstericiliği olmadan işimize yarayacak gözlemler yapamayız. Bilim insanı dünyaya hiçbir zaman boş bir kafayla bakmaz, kişisel eğilim ve inançlarından sıyrılarak incelediği konuya önyargısız ve tarafsız bir şekilde bakamaz; tersine zihninde önceden varolan hipotezleri dünyaya empoze eder, olayları kuramsal beklentileri doğrultusunda gözlemler ve yorumlar. Dolayısıyla önyargısızlık aslında bir önyargıdır. Üstelik bu kuramlar, insan aklının özgür yaratılarıdır, der. Bu aynı zamanda mantıksal pozitivizmin doğrulama (verification), belgeleme (confirmation) ve tümevarım anlayışının eleştirisi ve hatta reddi olduğu için felsefî düşünce açısından önemlidir.68

Popper, bu sıralamanın yerine şu aşamaları koymuştur: Sorun, önerilen çözüm, yeni kuramdan sınanabilir önermelerin tümdengelimsel çıkarımı, s1namalar, yani başka şeylerin yanı sıra gözlem ve deneyle yadsıma girişimleri, yarışan kuramlar arasında yeğleme yapılması. ${ }^{69}$ Görüldüğü üzere bu öneri de bilim gözlemle değil problemle başlar. Bilimsel sorunlar, genellikle yerleşik görüş ya da beklentilerimize ters düşen olaylardan, birbirleriyle ilişkisi yokmuş gibi görünen olayları birleştirme çabasından, kimi olayları da daha derinlemesine açıklama kaygısından doğar. Bilim insanı ele aldığı sorunu çözmek için emprik içeriği mümkün olduğunca zengin, sinanabilir bir kuram ortaya atar ve kuramını gözlemsel-deneysel olarak sinar. Gözlem ya da deney sonucu olumluysa yeni bir soruna yönelir, teorisini yeniden sınar, herhangi bir aşamada deney sonucu olumsuz çıkarsa kuram yanlışlanmış sayılır. Yeni bir kuram arayışı başlar ve bu böylece sürüp gider. Görüldüğü üzere bu tümdengelimsel, yani genelden özelin çıkarsanmasıdır. Genel geçerliliği olduğu düşünülen teorilerin, önermeler yanlışlanmadığı/çürütülmediği sürece geçerliliği "sağlanmış" olur. ${ }^{70}$

Peki, bu bir kısır döngü değil midir? Yani olgusal deneyimlerimizden ancak kuramlar biçiminde önceden onların içine koyduklarımızı çıarabileceği-

68 Irzık, agm, ss. 19, 23, 28

69 Magee, age, s. 51. Bu nedenle olsa gerek, genç bir bilim araştırmacısına hocası, git de gözlem yap" derse bu kötü bir ögüttür, onun yerine şunu demelidir: "İnsanların bu günlerde bilim alanında neleri tartıştığını öğrenmeye çalış, nerelerde güçlükler çıktığını anla ve çatışmalarla ilgilen." Magee, age, ss. 63-64.

70 Popper, Bilimsel Araştırmanın Mantı̆̆ı, ss. 56-57, 138 vd.; Irzık, agm, s. 24. 
miz sonucu çıkmaz mı? Bu soruya da Popper, yalnız kuramı doğrulayan olguları seçmediğimizi hatta kuramı yanlışlayacak olguları aramamız gerektiğini belirtir. Buradaki yanlışlanabilirlik terimi, bir anlam ölçütü olarak değil de bir sınırlandırma ölçütü olarak kullanılmaktadır. Bununla anlamlı iki önerme arasında bir ayrım yapar: Yanlışlanabilen ve yanlışlanamayan önermeler şeklindeki bu ayrımda, yanlışlanabilirlik, anlamlı dil kullanımı içinde bir sınır çekmektedir. ${ }^{71}$ Zaten Popper' in çözmekle övündüğ̈ iki temel problem de budur yani tümevarım ve sınır problemleri.

\subsubsection{Tümevarım ve Sınır Problemi}

“Bir teoriyi bilimsel kılan nedir ve amprik bilimleri sahte bilimlerden ve metafizikten ayıran ölçüt var mıdır?" soruları sınır problemini oluşturur. Bunun çözümü şudur: Bir teorinin bilimselliğinin gerekli şartı sınanabilir, yanlışlanabilir ya da çürütülebilir olmasıdır. Popper bu noktada yanlışlanabilirlik ile yanlışlama terimleri arasında bir ayırım yapar. Ona göre önemli olan yanlışlanabilirlik terimidir çünkü hipotezin yanlışlanabilir olması demek, amprik içeriğe sahip olması demektir. Amprik içerik ne kadar fazla olursa evren hakkında o kadar çok şey söyler ve yanlışlanma riski alınır. Onun yanlışlama potansiyeline sahip "temel önermeler" kümesi o kadar zengin, kuramın yanlışlanabilirlik derecesi de o kadar yüksek olur. Bunu salt önerme dizgelerinin görgül/emprik özelliklerinin ölçütü olarak ele alır. Önermelerin ne zaman yanlışlanabilir olarak kabul edileceği, konulan kurallarla belirlenir. Dolayısıyla yalnızca kabul edilen temel önermelerle çelişen bir kuram yanlışlanmış sayılır. ${ }^{72}$

Yukarıda bahsettiğimiz yarışan kuramlar arasında yeğlemede ölçüt, deney ve gözlem testlerine karşı koymakta başarısız kalan kuramlar elenmesi, bunların yerine daha spekülatif ve evrensel düzeyi düşük olan emprik/görgül varsayımlar konulmasıdır. Dolayısıyla bilim, deneme ve yanılmalar, varsayımlar ve yanlışlamalarla ilerler, sadece en güçlü teoriler ayakta kalır. "En güçlü teori, dünya hakkında çok kapsamlı tezler öne süren ve bu nedenle de yüksek derecede yanlışlanabilir olan; her ne zaman test edilirse edilsin yanlışlamaya direnen teoridir." 73 Buna Popper, 'bir kuramı denetlemek, kusuru olup olmadığını araştırmak' der. Ona göre bir kuramın denetlenmesini mümkün kılan dolay1-

71 Popper, age, s. 64, Dipnot 3.

72 Popper, age, s. 109 vd.; Irzik, agm, s. 19.

73 Magee, age, s. 21; Chalmers, age, ss. 83, 89-99. 
sıyla da onu bilimsel kılan husus bu yanlışlanabilme özelliğidir. Bu nedenle bilimsel araştırma yapanlarda "entelektüel bir alçak gönüllük" bulunmalıdır ki teorisinin hatalı ya da yanlış olabilme kaygısını taşımasıdır. Dikkat edilirse Popper'in çözümü, doğrulama ile yanlışlama arasında mantıksal açıdan bir asimetri (bakışıksızlık) olduğundan hareketle yapılır. Yani bir kuramın yanlışlanabilirliğini, kuramla temel önermeler arasındaki mantıksal ilişki olarak tanımlamak mümkündür. Temel önermelerden kasıt, mantıksal olarak olası ve ilke olarak gözlemlenebilir bir olayı tanımlayan bir önermedir. Bir kuram mantıksal olarak doğru ya da yanlış olması muhtemel bütün temel önermelerin oluşturduğu kümede kurama ters düşen önermeler bulunduğunda o kuram, yanlışlanabilir. O halde "yanlışlanabilir olma" kuram ile önerme ya da önermeler arasındaki salt mantıksal ilişkisi ortaya koyan bir yüklemdir. ${ }^{74}$

Mantıksal açıdan önermeler mantığıyla bu hususu tartışacak olursak bütün kuğular beyazdır" tümel önermesini olumlamak için yeryüzündeki kuğuların hepsini gözlemleme imkânı yoktur. Ama bu önermenin çelişiğini/değillemesini "Bazı kuğular beyaz değildir" ispatlamak için tek bir siyah kuğu gözlemlemek yeterlidir. Yani deneysel genellemeler, mantıkî anlamda doğrulanamaz ama yanlışlanabilir. Bu ise bilimsel yasaların ispatlanabilir olmasalar da sınanabilir olmaları demektir, onları yadsıma yolunda sistemli girişimlerle sınabilirler. ${ }^{75}$ Dolayısıyla Popper, tümevarımın doğrulanabilirlik ölçütünün dünyadaki anlamlı ve anlamsız önermeler arasındaki sınır çizmeye yeterli olmayacağını şöyle belirtir: Eğer böyle kabul edilirse; tekil önermeler deneysel açıdan ister doğrulansın isterse doğrulanmasın bilimsel yasalar gibi tümel önermelerin doğrulanmayacağı kesindir. Dolayısıyla doğrulamayı bilim ile bilim olmayan arasındaki ayıraç olarak kabul etmek, salt metafiziği değil aynı zamanda bütün doğa bilimlerini ortadan kaldırır. Her türlü metafiziği anlamsız ilan etmek gerekir, bunu söylemek, tarihsel olarak bilimin bir zamanlar sınanamayan dolayısıyla da metafizik kabul edilen efsane ve dinsel tasarımlardan çıktığını inkâr etmek demektir. Bu fizik ötesi önermeleri anlamsız görerek bir sınırlandırma değil onu aşmak, daha doğrusu yok saymak demektir. Hâlbuki bir zamanlar sınanamayan, şartların değişmesiyle birlikte sınanabilir ve bilimsel hale gelebilir. Örneğin evrenin ilk ilkesi olarak ileri sürülen atom, ya da Bacon'un hayali diye

74 Popper, Bilimsel Araştırmanın Mantığı, ss. 18, 107, 561. Bununla birlikte bilimin ilerlemesi ve gelişmesi düşüncesinin yanlışlanabilirlik anlayışındaki merkezi konumunun eleştirilere uğradığını belirtmek gerek. Chalmers, age, ss. 107-109.

75 Magee, age, s. 21; krş. Popper, Açı Toplum, c. 2, s. 228. 
karşı olduğu yerin hareketi teorisi zamanla bilimin konusu haline gelmiştir. ${ }^{76}$

Buraya kadar verilen bilgilerden Popper' in bilim ile doğruyu özdeş tutmadığı sonucunu çıkarabiliriz. Bilimdeki amacımız, doğruya yaklaşmaktır ama onunla tam bir örtüşme mümkün değildir.77 Çünkü hem Newton'un hem de Einstein' in kuramlarını bilim sayıyoruz, ama ikisi birden doğru olamaz, üstelik her ikisi de yanlış olabilir. Bunların yasalarına dair gözlemler, yaratıcı kullanımlar, bunların nihai doğru olduğu anlamına gelmez, ancak benzerlerinden daha kesin ve daha çok sayıda öndeyide bulunmaya imkan verebilir, ama her halukarda daha iyi bir kurama yerini bırakabilir. ${ }^{78}$ Popper, "tümevarım bir efsanedir" der ${ }^{79}$ çünkü dünyayı anlama girişimi kuralları olmayan bir iştir. Galile, Newton ve Einstein, yaratıcı dahiler olarak bu anlamayı gerçekleştirirken kuramlar geliştirmişlerdir. "Bir bilim adamının kafasında neler olup bittiğini sadece o bilir ve onu ve tanıyanların ilgilendirir. Peki, bu psikolojik durumun/ilginin bilim tarihi açısından önemi nedir? Ortaya konulan bilimsel kuram'ın bu tür öznelliği ile değil de iç tutarlılığı var mıdır? Varsa sahiden deneysel mi, yoksa totolojik midir? Denenmiş kuramlarla karşılaştırılınca ne gibi sonuçlar verir? Bu sorular önemlidir, dikkat edilirse tümdengelim süreçleriyle bundan gözlem ve deneyle sinanabilecek tekil önermeler biçiminde mantıksal sonuç çıkartacaklardır. Burada bilim adamının teorisine nasıl ulaştığı sorulmadığı gibi yapılan gözlem ve deneyler, kuramı oluşturmak söyle dursun, bir ölçüde ondan çıkarılmış ve onu sınamak amacıyla düzenlenmiştir. O halde bu bağlamda tümevarım diye bir şey yoktur, o bir efsanedir..$^{80}$

76 Magee, age, ss. 43-44; Popper, Bilimsel Araştırmanın Mantığı, s. 59. Tümevarımın temeli olan olgusal gözlem ve doğrulanabilirlik ölçütüne metafizik bağlamda yöneltilen bu eleştiriye rağmen, paradoksal bir şekilde, bir kez bilgi edinme sürecinde olgusal gözlem yöntem olarak bir yana itildi mi, mistisizme geçişin son derece kolaylaşacağını Reichenbach söyler. Reichenbach, Bilimsel Felsefenin Doğuşu, s. 31 .

77 Bunu söylerken Popper, “doğruluğun bilimin amacı olduğu tezini anlamı kılabilir miyiz?” ile “bu, bir teorinin doğru veya doğruya diğerinden daha yakın olduğunu öne sürmeyi anlamlı kılar mı?" şeklindeki birinci grup sorular ile "doğruluk gerçekten bilimin amacı mıdır?", "bir teorinin doğruya diğer bir teoriden daha yakın olduğunu nasıl bilebiliriz?" türü sorular arasındaki farka dikkat çeker. Bu epistemolojik problemin farkındadır. Alan Chalmers, age, ss. 210-212, 218-223.

78 Magee, age, ss. 26-27.

79 Popper, bununla matematiksel tümevarımı kastetmediğini özellikle belirtir. Kastı, sadece tümevarımsal bilimde, tümevarıma benzer bir şeyin, yani tümevarımsal bir yöntemin var olduğunu reddetmektedir. Bk. Popper, Bilimsel Araştırmanın Mantı̆̆ı, s. 64.

80 Magee, age, ss. 27-28; Buna yöneltilen muhtemel eleştiriler için aynı eserin ss. 29-30. 


\subsubsection{Yanlışlamacılığın Yanlışlanması!}

Yanlışlamacının iddiaları, Chalmers'e göre gözlem önermelerinin teoriye bağımlı ve yanılabilir olmaları gerçeğiyle ciddi şekilde çürütülür. Popper, gözlem önermelerinin kabul edilebilirliğinin testlere dayanma güçleriyle ölçüldüğüdür, testleri geçemeyen önermeler yanlışlandığ ${ }_{1}$ için reddedilir, testlere direnen önermeler ise korunur. ${ }^{81}$ Bilim tarihi, bunun gerçekten böyle olmadığını göstermektedir. Üstelik eğer yanlışlamacı metodolojiye uygun davranılırsa bilimsel teorilerin en iyi örnekleri arasında yer aldıkları kabul edilen teorilerin daha ilk aşamasında reddedileceği için hiçbir zaman geliştirilmeleri imkân dâhilinde olmayacakt1. ${ }^{82}$

Popper' in felsefesi, özünde" 83 derin bir epistemolojik kuşkuculuğu barındırır ve son tahlilde irrasyoneldir. Popper, sadece genel hipotezlerin tümevarımla desteklenmelerinin mümkün olmadığını söylediği için değil; aynı zamanda en temel önermeleri kabul etmek için bile "iyi sebepler" olamayacağını, ne kadar basit olursa olsun amprik hiçbir önermeyi belgelemenin ya da temellendirmenin (justification) mümkün olmadığını iddia ettiği için irrasyoneldir."

Şimdi felsefe tarihi açısından tümevarım sorununu inceleyen, onu bilimsel araştırmalarda kullanılan bir yöntem olarak geliştiren düşünür İbn Sina'nın bakış açısını ele alalım.

\section{3. İbn Sînâ'ya Göre Tümevarımın Tutarlılığı}

İbn Sînâ açısından düşünce/fikr ile elde edilen bilgi, tasavvur ve tasdik ile kazanilır. Tasavvur ilk bilgi olup herhangi bir öncüle gerek duymaz; beyaz ve insan tasavvurunda olduğu gibi ya tanımla (hadd) veya betimleme (resm) ile oluşur. Tasdik ise kıyas ve burhan ile çıkarsanmayla oluşturulur. Açıklanmak istenen yargıyı veren delil (hüccet) ya kıyasla yani bir şeyin başka bir şeyin ör-

81 Chalmers, age, ss. 116-120.

82 Newton'un çekim teorisi, ayın yörüngesiyle ilgili gözlemlerce bilim adamının zamanında yanlışlanmıştı. Ölümüne yakın Merkür gezegenin yörüngesinin ayrıntılarıyla uyuşmadığı da biliniyordu ama bu teori terk edilmedi. Diğer örnek için de bk. Chalmers, age, ss. 124-126; Irzık, agm, ss. 29-32; H. Poincare ve P. Duhem gibi uzlaşmacılar (convensionalist) doğa yasalarının hiç bir zaman hiç bir yöntemle yanlışlanamaz çünkü özellikle bilimsel anlamda gözlemin ve ölçmenin ne olduğunu belirleyenlerde bu yasalardır, şeklindeki eleştireler için bk. Popper, Bilimsel Araştırmanın Mantı̆̆ $\mathrm{l}$, s.102 vd.

83 Irzık, agm, ss. 32-33. 
neğine uygun olarak ölçülmesiyle ya da istikra ve benzeri ile elde edilir. Ama bunların dışında da tasdik olabilir zira tasdik sadece yargıya denir, doğruda olabilir yanlış da olabilir. Örneğin "İnsan bir kuştur" bir tasdiktir ama yanlış bir önermedir. Ayrıca tasavvur tasdiksiz olur, (örneğin "Boşluk mevcuttur" önermesinde olduğu gibi) ama tersi olmaz. ${ }^{84}$

\section{1. İstikra: Tanım ve Çeşitleri}

İstikra'nın sözlük anlamı, tek tek köylere yönelmektir. Bir yeri terk edip başka bir yere yönelerek ülkeyi dolaşmak gibi istikra yapan kimse bir tümel elde edebilmek için tikelleri tek tek dolaşması gerekir. ${ }^{85}$ İbn Sînâ, istikra'yı tümel/külli bir hükme, tikel/cüzilerin hepsinde veya bazılarında bulunduğundan hareketle ulaşmaktır, şeklinde tanımlar. ${ }^{86}$ Burada tasavvur edilen tasdik edilememiştir yani doğrulama veya yanlışlama gerçekleşmeyebilir. Zira tasavvur, (kıyas yoluyla) bir ifadenin tasdik edilmesiyle birlikte tüm akledilir bilgiyi (makulat) oluşturmaktadır. Tasavvurun yaptığı şey, zihne tanım ve terimleri getirmek ve kıyaslar oluşturmak için onları birleştirmektir. Ayrıca zihnin tekil bir anlamdan bir şeyin tasdikine geçmesi mümkün değildir. Çünkü tekil anlam, zatında veya halinde varlığı veya yokluğu belirginleşmediği surece yeterlilik sağlanmad1ğından başkasının tasdikine götürmez. Bu nedenle tasavvur tarif/had ile tasdik kıyas ile kazanılır, denilir. Tasavvur ise çoğu kez tekil bir anlamda gerçekleşir, ama bu da pek az şeyde olur, üstelik çoğu durumda eksik veya güdüktür. ${ }^{87}$

İstikra duyuya dayanır ve zati istikra denilir. Duyuların her zaman yanılma ihtimali güçlü olduğundan dolayı yakini bilgi verme ihtimali zayıftır, hatta küllî/tümel hüküm veremez, demek daha uygundur, bu nedenle istikra da temelde doğru olma ihtimali bulunan (zannı galip) bir bilgi verebilir. Ya da başka bir ifadeyle istikranın doğru bilgiye ulaştırması zorunlu değildir. Nitekim İbn

84 İbn Sînâ, İ̧aretler ve Tembihler, ss. 3, 50; a.mlf., Kitabu'n-Necat, haz.: Macid Fahri, Beyrut 1985, ss. 43, 97; el-Cür, el-Fahuri, age, s. 166.

85 İbn Sînâ, İşaretler ve Tembihler, ss. 3-4, 50. Kıyas-tümdengelim ve istikra ile ve benzeri ibaresinden kasit, temsil-analojidir. Fakihlerin kıyas dediği budur; zira o bir hükümle ilgili olarak bir tikele başka bir tikeli iliştirmeyi ifade eder. Bk. Nasiruddin Tusî, eş-Şerhu'l-Iş̧arat ve'tTenbihat, İbn Sînâ'nın aynı adlı eseriyle birlikte yayımlayan Süleyman Dünya, Beyrut 1992, ss. 136-137.

86 İbn Sînâ, "Uyun el-Hikme", İbn Risaleleri, ed.: Hilmi Ziya Ülken, İstanbul Üniversitesi Edebiyat Fakültesi Yay., Ankara 1953, ss. 9-10; en-Necat, s. 93; Yaren, age, s. 96.

87 İbn Sînâ, Medhal, s. 15; “II Analitikler”, Kitabu'ş-Şifa, ss. 1-3; Gutas, İbn Sînâ'nın Mirası, s. 118; Ülken, "İbn Sînâ", c. 5/2, s. 809. 
Sînâ, istikra'yı bir tümel hakkında -onun tikellerinin hepsinde veya bazılarında bulunduğu için- bir hüküm koymak olarak tanımlayarak bu tür bir çıkarıma güvenilemez, der. Örnek olarak da "Her hayvan bir şey çiğnerken alt çenesini oynatır" sonucuna varılmasını verir. Zira belki de gördüğün hayvana benzemeyen (timsah gibi) başka bir hayvan bulunabilir. ${ }^{88} \mathrm{Bu}$ nedenle duyumlarla tasdiklenen tecrübî bilgi ile teyit edilmesi gerekir. Ancak bu sayede külli/tümel bilgi verebilir. Buradaki tikellerin hepsinde veya bazılarında bulunanların incelenmesi sözünden hareketle tam ve eksik tümevarım ayrımını yapabiliriz.

\subsection{Tam Tümevarım}

Eğer bütünü/külliyi oluşturan tikellerin tamamını inceleyerek hüküm verilirse buna tam tümevarım denir. Buna "burhânî istikrâ" da denir çünkü küllinin bütün fertlerinin incelendiği istikrâdır. Bu, aslında şekle bağlı bir tümevarımdır zira bu tümevarım temelde kıyastır çünkü belli sayıdaki nesnelerin tek tek incelenmesi sonucu belli bir hükmün incelenenlerin hepsi için verilmesi demektir. Bundan dolayı tümevarım yerine burhan denilmesi daha uygundur, denilmektedir. Bu çıkarım türünde yakini önermelerden yakinî bilgiler kıyasla üretilir. Yakini olanlar ise evveliyat (apriori), tecrübeler, mütevatirat, mahsusat (duyulurlar) makbulat ve maznunattan oluşur.

Burhan, burhanu'l-mutlak (limmi) ve burhanu'l-inni diye ikiye ayrılır. İlki, hükmün nedenini ortaya koyar veya nedeniyle beraber ortaya konulan hükümdür de diyebiliriz. Bu salt tasdik değildir, ondan öte zihindeki nedeni de ortaya koyarak yapılan bir tasdiktir. Ayrıca sonucun dış dünyadaki tasdikinin nedenini de vermesi önemlidir. Zira onun neden böyle olduğunu bilinir hale gelir. Orta terim, hem kişinin sonucu tasdik etmesinin hem de sonucun varlığ1nın tasdikinin nedenidir, zira büyük terimin illetidir. Artık o sonuca ulaşmanın sebebi bellidir. Burhanu'l-inni ise zihinde sonucun taraflarının bulunmasını ve tasdiki sağlayan şeydir ama tasdik zorunlu değildir. Lime'deki gibi bir sonuca varılmaz zira orta terim, büyük terimin illeti değildir ayrıca büyük terimin küçük terimde bulunmasının da illeti değildir. Hatta malulü bile olabilir. ${ }^{89}$ Yukarıda mantıkta aşkınlık hususunu Kant ile birlikte gündeme gelmesinin tutarlı olmadığını, ondan çok önceleri, İbn Sînâ'nın eşyanın mahiyetinin bir zihinde

88 İbn Sînâ, İ̧saretler ve Tembihler, s. 50; “Uyunu'l-Hikme”, Risaleler, çev.: A. Açıkgenç, H. Kırbaşoğlu, Kitabiyat Yay., Ankara 2004, ss. 74-75; Tusî, age, s. 367.

89 İbn Sînâ, "el-Burhan/Mantık”, Kitabu'ş-Şifa, tahk.: Ebu'l-Ala Afifi, 1385, s. 55; "II Analitikler", Kitabu'ş-Şifa, s. 5. 
bir de dış dünyadaki varlıkları olduğunu belirterek mantığın konusunun mahiyetin zihindeki bulunuşu sırasında ortaya çıkmasını bir de bu çerçevede değerlendirmek gerekir. ${ }^{90}$

Bu noktada kıyas ve tümevarımın küçük ve orta terimin yer değiştirmesiyle birbirinden farklılaştığını belirtmek gerekir. Buna dair örnek ise şöyledir: Kıyas, "Her insan, at ve kuş hayvandır. Her hayvan alt çenesini oynatır." şeklinde; tümevarım ise "Her hayvan, ya bir insan ya bir at, ya bir kuştur. Bunların tamamı alt çenesini oynatır" şeklinde düzenlenir. Oysa bunların dışında olan hayvan vardır, bizim gözlemlememiz hayvan olmadığı anlamına gelmez. Buradaki eksiklik küçük terim açısındandır. Bütüncül bir belirleyiciliği içeren ise tam tümevarımdır. Bunun dışındakiler ise eksik diye nitelendirilir ve zandan başka bir şey ifade etmez..$^{91}$ İbn Sinnâ bu konuda şunları söyler: Küçük terimde büyük terim bulunduğu için orta terimde büyük terimle hüküm verilir. Örnek olarak “Her canl1/hayvan uzun ömürlüdür. Uzun ömürlü olmak tekrarı az görülen bir niteliktir. İnsan, at ve öküz bu tür hayvanlardandır. Dolayısıyla bunlar uzun ömürlüdürler. Bu eksik (meşhur) istikradır çünkü bütün canlılar bunlardan ibaret değildir, ömürleri kısa olan birçok hayvan vardır ve bunların hepsini tek tek saymak zordur. ${ }^{92}$ Aslında tam tümevarım denilen burhandır, kıyastır, tümevarım denilince bu eksik olan anlaşılır, şeklinde vurgunun nedeni budur.

Görüldüğü üzere bu ancak kıyas ve istikra ile yapılır, tecrübe ile teyit edilir. Zaten duyulardan elde edilen akledilebilirlerin (makuller) sıralamasında (bilaraz, cüz'î kıyas, istikrâ, tecrübe) bu hususu gözlemlemekteyiz. ${ }^{93}$ Bu tespit önemli, zira mutluluk Aristotelesçi anlamda (eudaimonia) akledilebilirlerin herhangi bir engel olmadan ebedi olarak düşünülmesiyle elde edilir. Semavî akıllar tarafından zamana bağımlı olmaksızın bir anda ama kıyası oluşturan önermelerin terimlerine ait belirli bir düzene göre yapılan bir düşünmedir bu. Dolayısıyla kıyasların sonuçları tek tek makulleri ifade eder ve ilk öncüllerden başlamak suretiyle sırasıyla gerçekliği tanımlayan diğer ifadeleri ispat ederek ilerleyen müteselsil adımlar şeklindedir. ${ }^{94}$ Burada dikkat edilmesi gereken husus, aklın makulleri seri bir şekline hangi yolla elde edebildiğidir. Buna verile-

90 Durusoy, İbn Sinnâ, ss. 182-183.

91 Tusî, age, ss. 366-368.

92 İbn Sînâ, en-Necat, s. 93.

93 İbn Sînâ, el-Burhan/el-Mantık, Kitabu'ş-Şifa, s. 98, 222-224; İbrahim Medkur, Takdim, İbn Sînâ, "el-İlahiyat", Kitâbu'ş-Şîfâ içinde, tahk.: G. C. Kanavati, Said Zayed, ts., s. 38.

94 Gutas, İbn Sinnâ'nın Mirası, ss. 37-38. 
cek cevap, aklın bi'l-meleke durumundan müstefad (kazanılmış) veya bi'l-fiil akla nasıl yükseldiğini de açıklaması bakımın önemlidir. İbn Sînâ, Aristoteles geleneğini takip ederek orta terimi bularak cevaplanacağı kanaatindedir. İnsan aklı orta terimi bulursa/keşfederse faal akılla ittisali de gerçekleştirmiş olur. İttisal adı verilen bu durum, gerçek anlamda saadetin elde edilmesinden başka bir şey değildir. ${ }^{95}$ Ama bunun tümdengelimsel bir kıyasta geçerli olduğunu unutmamak gerek.

Bu sistemde akletmenin faili (insan aklı), akletme süreci (orta terimi keşfetme) akletme yöntemi (mantık) ve akletmenin nesneleri (makuller) birbiriyle ilintili ve birbirini açıklayan bir ilişki içinde biraya getirilmiştir. ${ }^{96}$ Fakat bu istikranın tam olabilmesi için yakînî öncül gerekir. Ancak burada cüzi önermelerin de yakin olması şarttır. ${ }^{77}$ Bu noktada yakînî önermelerde yüklemi konuya bağlayan şeye dikkat edilmesi gerekir zira bu (tam) istikrâ olamaz. ${ }^{88}$ Bu nedenle yakine yakın ya da cedelî tasdikte kıyas, meşhur ya da bütün cüzilerinin incelenmediği eksik istikradan oluşur. ${ }^{99}$

\subsection{Eksik Tümevarım}

Bir de bütünü/külliyi oluşturan tikellerin bazılarını veya bir kısmını inceleyerek o külli hakkında tümel bir hükme ulaşma vardır. Buna eksik veya büyültücü tümevarım denir. Burada bütünün bir kısmı ile ilgili tespit, o bütünün tamamı hakkında geçerli sayılmaktadır. Birincisinde sonuç akıl için zorunlu, ikincisinde ise olumsaldır. Gözlem ve deneye dayanarak bilimde önemli işlevi olan bu tümevarım yöntemine yöneltilen eleştiri noktası tam budur, çünkü bugün gerçek-

95 Gutas, İbn Sînâ'nın Mirası, ss. 39,42, 9, 100-112; M. S. Aydın, “İbn Sinâ’da Ahlak ve İnsanın Mutluluğu", İbn Sînâ Kongresi Tebliğleri, Erciyes Üniversitesi Matbaası, Kayseri 1984, s. 243. İbn Sînâ'nın bilgi teorisine yönelik eleştiriler için bk. Şehristânî, Filozoflarla Mücadele, çev.: Aygün Akyol, Aytekin Özel, Litera Yay., İstanbul 2010, ss. 44-58; Aygün Akyol, Şehristânî'nin Filozoflarla Mücadelesi, Araştırma Yay., Ankara 2011, ss. 92-114; Şehrezûrî Metafiziği, Araştırma Yay., Ankara 2011, ss. 172, 173, 174; İbn Haldun, Mukaddime, tahk.: Ali Abdulvahid Vafi, Daru Nahdati Misır, Misır trs., c. III, ss. 1210, 1211, 1212; Aygün Akyol, “İbn Haldun'un İlim Anlayışında Felsefe ve Tarih Tasavvuru", Hitit Üniversitesi İlahiyat Fakültesi Dergisi, 2011/2, c. 10, say1: 20, ss. $41,42$.

96 Gutas, İbn Sinnânnn Mirası, s. 44.

97 İbn Sînâ, Burhan: II Analitikler, s. 79.

98 İbn Sînâ, age, ss. 93-94.

99 Diğer tasdik türünde ise (Belaği tasdik) makbulat ya da mümkün önermeler kullanılır. Fârâbî, Kitabu'l-Burhan, s. 60. 
leşen bir olaya ait hüküm, daha sonra ortaya çıkacak benzer bir olay hakkında geçerli sayılabilir. ${ }^{100}$

İbn Sînâ da bu tür bir çıkarıma güvenilemez der. Çünkü burada fertlerin tek tek sayımı yoktur, cedeli kıyastaki gibi meşhur öncüllerden kurulum vardır. Yani bütün duyulur, tecrübî veya evveli/ilksel öncüller, ya meşhurdur ya da meşhur hükmündedir dolayısıyla bu tarz, görünüşte tam olan veya tam olduğu varsayılan (cedeli) tümevarım çeşididir. ${ }^{101}$ Örnek olarak da, "Her hayvan bir şey çiğnerken alt çenesini oynatır" sonucuna varılmasını verir. Zira belki de gördüğün hayvana benzemeyen ve incelenmeyen (timsah gibi) başka bir hayvan bulunabilir. ${ }^{102}$ Demek ki tam tümevarımın güvenilmezliği kendi içinde eksik tümevarım barındırmasından kaynaklanır. Bu nedenle, İbn Sina yukarıda belirttiğimiz üzere, istikra tecrübeyle desteklenmeli görüşündedir. Ama bu yapılsa bile, yani tecrübe ve istikrâ ile kuzgunun siyah olduğu ortaya konsa bile, siyahlığın kuzgunda zâtî olduğu ispatlanmadıkça kesinlik ifade etmeyeceğini belirtir. ${ }^{103}$ Bu tasavvursuz tasdik olamaz, ama tasdiksiz de mahsusat bilinemez deyip, tasdik için de duyuların önemini belirtmesi açısından önemlidir. Kar beyazdır, güneş ziyadır, hükümleri ancak duyularla tasdik edilebilir. İbn Sînâ'nın hissi tecrübelerle elde edilen bilgilere mahususat diyerek, tecrübenin gerçekleştirdiği rolün tecrübesiz, kıyassız elde edilemeyeceğini belirtmesi önemlidir. ${ }^{104}$ İsste tam bu noktada, İbn Sînâ'nın öncüsü olan Fârâbî'nin “Tecrübe, istikradan farklıdır. Tecrübe, tümel/külli hüküm hakkında zorunlu bir bilgi verirken istikra tümel hakkında kesin bir bilgi vermez. Çoğu zaman, tecrübe ile istikra birbirine karıştırılmaktadır" tesbiti önemli ve zihinden çıkmaması gereken bir hususa işaret etmektedir. ${ }^{105}$ İbn Sînâ' da aynı görüştedir, ikisi arasındaki fark malumdur, açıktır. İstikra ya delil getirme ya da tenbih/uyarı yoluyla yapılır. ${ }^{106}$ Ayrıca "Doğruluk değeri açısından önermelerin yapısını" incelerken İbn Sînâ, Kıyas yapanlar ve bunların yolundan gidenlerin kabul ettiği önermelerden bahseder. Burada kabulü zorunlu olan önermeler olarak apaçık olan ilk doğruların gözlem, deney, sezgi, rivayet ve kanıtı kendi içinde olan önermeler

100 Yaren, age, s. 95.

101 İbn Sînâ, Burhan: II Analitikler, s. 5.

102 İbn Sînâ, İşaretler ve Tembihler, s. 50, Uyunu'l-Hikme, ss. 9-10, Yaren, age, s. 96.

103 İbn Sînâ, el-Burhan, s. 86.

104 İbn Sînâ, en-Necat, s. 97-98; Günaltay, agm, s. 15.

105 Fârâbî, "Kitabu'l-Burhan", el-Mantık ınde'l-Fârâbî, tahk.: Macit Fahri, Beyrut 1986, ss. 24-25.

106 İbn Sînâ, en-Necat, s. 102. 
türünden deneye dâhil olanlardır, demektedir. ${ }^{107}$ Kıyasçların yöntemini benimseyenlerden kasıt, istikra ve temsil yöntemini kullananlardır. Bunlar açısından önermeler, ya tasdik edilir ya tasdikin dışında bir etki (imgelem-tahayyül) gerekir ya da bu ikisinden hiç birine gerek duyulmamasıdır. Sonuncu zaten kullanılmaz. Ama önemli olan kabulü zorunlu-vacip olan önermelerin hemen yanında gözlem (müşahadat) ve deneyimlerimizin (mücerrebat) zikredilmesidir. Gözlemlerden kasıt, beş duyu ile kavranan, algılananlara dayanılarak yargıda bulunulmasıdır. Güneşin ısıtması ve yakıcı olması önermesindeki yargı doğru, tutarlı bir hükmü ifade eder. Deneyimlerimiz sürekli tekrarlanan gözlemlerimiz sonucunda oluşan yargı ve önermeleri ifade eder. Sürekli tekrarlanmasından dolayı bu gözlemler, birçok hatırlamayı temin eder. Bu hatırlamalar artık şüphe içermeyen bir kesin bilgi haline gelir. ${ }^{108}$

O kadar ki mantıkçı bu kesinlik duygusunun nedenini sormamalı zira deney, bazen doğruluğu kesin, bazen çoğunlukla olan önermeler gerektirir. Ayr1ca deney, "Odunla vurmak acıtır” önermesinde olduğu gibi gözlemlere karışmış bir çeşit gizli kıyası da barındırır. Bu örnekte görüldüğü gibi, tecrübe, nefsin ittifakla oluştuğundan emin olmasıyla kesinlik ifade eder. Üstelik buna bir de sezgisel deneyimler ilave edilebilir. Bu zihinlerden şüpheyi ortadan kaldıran kesinlik veren bir hüküm ilkesidir. Benzer bir durum mütevatir önermelerde görülür. Benim Mekke'yi görmemem, onun hakkındaki tevatüren gelen bilginin yanlış olmasını gerektirmez. Zira kesinlik, gözlemlemelerin sayıları ile değil, gözlemin yeterliliğiyle kazanılır. ${ }^{109}$ Tusî'ye göre, ilkinde gözlem sezgisel, doğrudan ve kolaylıkla elde edilir, ama ikincisi o kadar kolay değildir. Zira ilkinde gözlem sezgisel, doğrudan ve kolaylıkla elde edilir, ama ikincisinde elde edilmiş, kazanılmış bilgiler olmalı ve ona göre bir kıyas yapılmalıdır. Mütevatir önermeler, hadsi kategorisinde olup bu ikisine de yani hem sezgisel hem de sezgisel olmayıp kazanılmış bilgilere ve bunlara dayanan kıyasa ihtiyaç duyar. ${ }^{110}$

\subsection{Tümevarım ve Tecrübe Birlikteliği}

Metnin başında tümevarımlı çıkarımlarda ihtimalliğin öznel olması hususun-

107 İbn Sînâ, İşaretler ve Tembihler, s. 50; krş. en-Necat, ss. 97-100.

108 İbn Sînâ, İşaretler ve Tembihler, ss. 50-51, Tusî, age, ss. 341-343.

109 İbn Sînâ, age, ss. 51-51; en-Necat, s. 98.

110 Tusî, age, ss. 341-344. 
dan bahsetmiştik. Bunu söylemek, onların her türlü akılcı dayanaktan yoksun olduğunu anlamına gelir mi? Belki burada güvenilir bilgi niteliğinde olmayan ham tecrübe ile gözlem ve deney ile işlenmiş, arındırılmış tecrübe arasında bir ayrım yapmak gerekir. İbn Sînâ'nın ifadesiyle söyleyecek olursak, “duyumsanan/mahsus, tümevarımla ulaşılan ve tecrübe arasındaki fark şudur: Duyumsanan, kesinlikle tümel bir görüş vermez. Diğerleri ise bazen tümel/külli bir kesinlik bildirirler." Burada tümevarım ve tecrübe edilen arasında tekrar bir ayrım yapan İbn Sînâ, ilkinin ister şartlı isterse şartsız olsun herhangi bir tümelliği zorunlu kılmadığını söyler. Eğer bir tecrübeye indirgenirse tümelliği zorunlu kılar, yoksa galip zan oluşturur. ${ }^{111}$

$\mathrm{Bu}$ husus, tecrübeyi tümevarımdan farklı kılması açısından önemlidir. Tümevarımda sorun varlığın kendisinde yüklem ile konu arasında bir sebep bulunup bulunmama durumundan kaynaklanır. Eğer sebep olan orta terim kılınırsa, tek bir sebep aracı yapılmış olur, bu imkânsızdır zira sebep olmadığı varsayılmıştı. Bu gibi hususların tamamı ya kendiliğinden açıkır ki bu bizim konumuz dışındadır ya da açıklaması tümevarımla yapılmasıdır. Konumuz tümevarımla yapılan açıklamalarda ya yüklemin konunun tikellerine nispetinin varlığını bir sebep bulunmaksızın kendiliğinden açık olmasıdır; tümevarımdan kasıt budur. Ya da yüklemin konunun tikellerine nispetinin varlığının bir sebep ile olduğunu söyleyeceğiz. İşte bu durumda açılama ancak duyularla yapılır. Duyularla yapılan ise sürekliliği getirmediği gibi ortadan kalkması mümkün olan bir durumun ortadan kalkmasını gerektirmez; yani bu öncüllerden hiçbiri kesin olmaz. Akılla açıklanması da mümkün değildir. ${ }^{112}$ Ama tümelin tabiatına ilişenin tüm tikellere iliştiğini dikkate alırsak yüklemin nispetinin arazi genel olduğunu ve tikellerin her birinde onun sebebiyle açıklanmaya gerek duyduğunu biliriz. Bu durumda tikellerin tümevarımın aracısız (orta terimsiz) olanı kesin bir şekilde tasdikimizin sebebi olması ve bunun tikellerde kendiliğinden açık olması iptal olunur. ${ }^{113}$

Tikelin sebepte birleşmesi gerektiği durumda, sebep öncelikle tümel anlama ait olur, tümele yarar sağlamayınca tikele de yarar sağlamaz, tümele yarar sağlandığında yarar sağlayan tümel nezdindeki kıyastır, tümevarım değil. Yüklemin konunun tikellerine bakıldığında bir sebep bulunmadığı durumda, ya kendiliğinden açık olur, bu mümkün değil ya da başka bir tümevarım gerekir

111 İbn Sînâ, Burhan: II. Analitikler, s. 45.

112 İbn Sînâ, age, s. 40.

113 İbn Sinâ, age, s. 41. 
ki bu da kısırdöngüdür. İste tecrübe burada devreye girer. Tıpkı sakamonya, safrayı ishal eder, hükmünde olduğu gibi sürekli tekrarlanmasından/tecrübe edilmesinden dolayı zihin kıyasla bir hükme ulaşır. Eğer bu sebebi bilinmeyen bir durumdur, buradan inanç dönüşen bir hüküm nasıl çıkartılır denilirse bu ilişkinin tesadüf olmadığı apaçıktır hatta zorunludur. Orta terim, yani ishal eden güç ki bu sebeptir, bunun vasıtasıyla büyük terimin küçük terim için varlığı ortaya çıkmaktadır. Burada büyük terimin orta terimdeki varlığının illeti olan bir aracılığıyla yapılan bir açıklama olduğu için kesinlik bizde bir sebeple meydana gelmektedir. ${ }^{114}$

Bu tecrübî bilginin tümevarımsal bilgiden farkı nedir? İstikra, ya tüm k1sımları sayıldığı için tam ya da bu mümkün olmadığı için zannî bilgi veren eksik tümevarım şeklinde olur oysa tecrübe böyle değildir; ${ }^{115}$ yalnız bir hüküm üzerine algılanan şeylerin sürekliliği veya çokluğu nedeniyle bilgi ifade etmekten öte, bir kıyasın kendisiyle birlikteliği nedeniyle bilgi ifade eder. Üstelik tecrübî bilginin mutlak tümel kıyasi bir bilgi olmadığı da açıktır. Bir şartla tümel bilgi verir, o da duyunun tekrar algıladığı bir şeyin doğası, herhangi bir engel olmadığı sürece duyunun tekrar tekrar algıladığı tarafta sürekli bir durumu gerektirmesi halidir. Ancak o zaman mutlak tümel bilgi verir. Burada tecrübe, eğer kendisinde bizatihi tecrübe edilenin alındığı bir tecrübe olduğu için kesinlik bildirir. Eğer tecrübe edilenden daha genel veya daha özel olan başka bir şey alınırsa bu durumda tecrübe kesinlik bildirmez zira bilaraz olan bizzat olanın yerine konulmuştur. Bu nedenle yanıltabilir ve zan ifade eder, kesin bilgi değil.116

Bu noktada önemli olan, tecrübenin yanılgıdan emin kıldığını söylemek yerine çoğunlukla tecrübe nedeniyle bize kesinlik iliştiği hususudur. Dolayısıyla kesinliği gerçekleştiren şeyin gerçekleştirme yönünü talep etmek gerekir. Bu ise bi'l-araz bir şeyin alındığından emin olmayı gerektirir. ${ }^{117}$ Evet, tecrübe, deneyim olması bakımından mutlak tümelliği vermez, ancak kendisine eşlik eden kıyasla birlikte tecrübî düşünceyle var olanı daha özel bir anlamdan men ederse, tek başına tecrübe hem kayıtlı hem de mutlak tümellikle kesinlik meydana getirir. Kısacası bizim koştuğumuz şartla meydana gelen şeylerde ve yalnızca

114 İbn Sînâ, Burhan: II. Analitikler, s. 42; en-Necat, s. 98.

115 İbn Sinâ, Burhan: II. Analitikler, s. 42.

116 İbn Sînâ, age, s. 43.

117 İbn Sînâ, age, ss. 4-44. 
bunların illetlerinin dikkate alınmasında tecrübe dikkate alınır. ${ }^{118}$ Ancak bu durumda bile gözlem ve deneyin kuram yüklü yani ham tecrübe yığını içinden ayırt edebilmek için temellendirmek istenilen teorinin kendisine başvurmak gerektiği unutulmamalıdır. Dolayısıyla bir kuramın gözlem ve deneyle temellendirilmesi döngülüdür.

Buradan çıkaracağımız sonuç, deneyci ve tümevarımcı yöntemin hiçbir işe yaramadığı ve tecrübeden yoksun mantık boştur sözü tutarlı değildir. Evet, mantıktan yoksun tecrübe Kant'ın deyimiyle "kör"dür, ama Mantık, tecrübeye dayanmaksızın soyut gerçekliğin (özellikle matematiksel nesnelerin) bilgisini sağladığı için "boş" değildir. ${ }^{119}$ Üstelik Reichenbach'ın ifadesiyle söyleyecek olursak gözlem ve deney üzerine kurulu emprizmin Bacon'a peygamberini, Locke'da liderini, Hume'da ise eleştirmecisini bulduğunu söylemesi bu bağlamda anlam kazanmaktadır. ${ }^{120}$ Tabii buradaki kasıt, gözlem ve deneye dayanan bir tecrübedir ki, İbn Sînâ bu deneyimin istikra ile birlikte uygulanması gerektiğini belirtir. Zira sorun varlıkta yüklem (mahmul) ile mevzu/konu arasında sebep bulunmadığı zaman çıkarım ilişkisinin nasıl kurulacağından çıkmaktadir.

\section{Sonuç}

İster eksik ister tam tümevarım olsun genelliğin en üst derecesine varmak hedeflenir dolayısıyla fertlerin tamamına ulaşmak gerekli değildir. ${ }^{121}$ Aristoteles ile İbn Sînâ'nın tümevarım anlayışı ile Bacon'un anlayışı arasında bir fark vardır yani tümevarımda özel/türden genel/cinse geçiş vardır. Oysa Bacon da özel, tek bir olayı, genel ise bir kanunu ifade eder. ${ }^{122}$

Bunlardan cins, hakikatleri farklı olan muhtelif nesnelere "Bunlar nedir?" diye sorulduğu zaman verilen cevaptır. Tür (nev) ise "Bu nedir?" sorusuna verilen cevapta iki külliden daha özel olandır. ${ }^{123}$ Tümevarıma yöneltilen eleştiride bu iki kavram merkezlidir zira tür, verilmiş sınırlı tikeller topluluğu değil

118 İbn Sînâ, Burhan: II. Analitikler, s. 44.

119 Grünberg, Felsefe ve Felsefi Mantık, ss. 371,373.

120 Reichenbach, Bilimsel Felsefenin Doğuşu, s. 63.

121 Yaren, age, s. 96.

122 Yaren, age, s. 98.

123 İbn Sînâ, İbn Sînâ, “Uyunu'l-Hikme”, İbn Risaleleri, ss. 2-3, krş. Risaleler, çev.: A. Açıkgenç, H. Kırbaşoğlu, Ankara 2004, s. 65; Yaren, age, s. 96. 
sınırsız tikeller topluluğudur dolayısıyla tam olarak saymak mümkün değildir. Ama eksik tümevarım zaten bunun üzerine kurulu olduğu için uygulama alanı vardır. Hem, müşahede veya tecrübe ile istikra yöntemleri her ilimde birlikte kullanılması da gerekmez. İ̉n Sînâ, bu açıdan nefse ait amelleri, tasavvur, tasdik, istidlal ve tertip, aslında yöntemden başka bir şey değildir, der. Çünkü kavramları, hükümleri, delilleri zümrelere ayıran ve tertip eden yöntemdir. Bu metot sayesinde insanlık bilgisi, ait oldukları konulara göre tertip edilerek çeşitli ilimler ortaya çıkmıştır. ${ }^{124}$

Bu süreçte istikra önemlidir zira ilim temelde tasniften ibaretse, tasnif de nesnelerin keyfiyetleri arasındaki benzerlikleri (analojileri) keşfetmekse bunun tam anlamıyla yapılmasının da imkânsız olduğu malumdur. Zira eşya/nesnelerin keyfiyetleri arasında gözlemlenen çeşitli münasebetlerin gizli sebepleri, illetleri bizim açımızdan kapalı ve meçhul kalır. Bu nedenle bu münasebetler hakkındaki hükümlerimiz birer eksik tümevarımdan öteye gitmez. ${ }^{125}$ Ve bu bir kısırdöngü gibi duruyor ama aslında öyle değil çünkü matematik bilimler gibi burhanı kesin ve istidlali olan bilimlerin yanı sıra burhanı istikrai olan ilimler de vardır. Tabiat bilimlerinde istikra ve tecrübe şarttır. Bunların dışında bir de ahlak ve toplum (ictimaiyye) bilimleri gibi genel yöntemlerden başka istatistik ve tarih tenkidi gibi bazı özel yolları ihtiva eden ilimler vardır. ${ }^{26}$ Bu tasnife de yönelik eleştiriler olabilir, fakat önemli olan istikra, gözlem ve tecrübenin bilimsel araştırma yöntemlerinde yeri olmasıdır. Bir filozof ve bir bilim adamı olarak İbn Sînâ'nın başarılarında bu yöntemin önemli katkısı vardır. Birçok olay, gözlem ve deneyle incelenmiş, sonuç genel bir önermeyle ifade edilmiş, uygulanmıştır.

\section{Kaynakça}

Akyol, Aygün, Şehristânî'nin Filozoflarla Mücadelesi, Araştırma Yay., Ankara 2011.

-------, Şehrezûrî Metafiziği, Araştırma Yay., Ankara 2011.

-------, “İbn Haldun'un İlim Anlayışında Felsefe ve Tarih Tasavvuru”, Hitit Üniversitesi Illahiyat Fakültesi Dergisi, 2011/2, c. 10, sayı: 20.

Aristoteles, Organon III: Birinci Analitikler, çev.: H. Ragıp Atademir, Milli Eğitim Bakanlığı, İstanbul 1996.

-------, Organon IV: İkinci Analitikler, Milli Eğitim Bakanlığı, İstanbul 1996.

-------, Nikomakhos'a Etik, çev.: Saffet Babür, Ankara 1997.

124 Günaltay, agm, s. 19.

125 Günaltay, agm, s. 20.

126 Günaltay, agm, ss. 20-21. 
Arslan, Ahmet, “Aristoteles”, İlkçağ Felsefesi Tarihi 3, İstanbul Bilgi Üniversitesi Yay., İstanbul 2007. Aydın, M.S, “İbn Sînâ' da Ahlak ve İnsanın Mutluluğu”, İbn Sînâ Kongresi Tebliğleri, Erciyes Üniversitesi Matbaası, Kayseri 1984.

Bruhl, Levy, Önsöz, Hume, David, İnsan Zihni Üzerine Bir Araştırma içinde, çev.: Selmin Evrim, Milli Eğitim Bakanlığı, İstanbul, 1986.

Chalmers, Alan, "Bilim Dedikleri”, Bilimin Doğası, Statüsü ve Yöntemleri Üzerine Bir Değerlendirme, çev.: H. Arslan, Vadi Yay., Ankara 1994.

Durusoy, Ali, “İbn Sînâ'nın Klasik Mantığa Katkıları”, İslam Felsefesinin Sorunları Sempozyumu Bildirileri, Ankara 2003.

-------, Metinlerle Mantığa Giriş, İstanbul 2006.

el-Gazzali, el-Mustasfa min ilmi'l-Usul, Daru İhya'il-Turasi'l-Arab, Beyrut, ts.

el-Fahuri, Hanna ve el-Cür, Halil, Tarihu'l-Felsefeti'l-Arabiyye, Beyrut 1982.

Fârâbî, “Kitabu'l-Burhan”, el-Mantık inde'l-Fârâbî, tahk.: Macit Fahri, Beyrut 1986.

------, İhsâu'l-Ulûm/İlimlerin Sayımı, çev.: Ahmet Ateş, Milli Eğitim Bakanlığı, İstanbul 1990.

Fazlur Rahman, "İbn Sînâ”; İslam Düşünce Tarihi, ed.: M. M. Şerif, İstanbul 1990.

Gutas, Dimitri, İbn Sînâ'nın Mirası, der.: ve çev.: M. Cüneyt Kaya, Klasik Yay., İstanbul 2004.

Günaltay, M. Şemseddin, “İbn Sînâ ve Mantık”, Büyük Türk Filozofve Tıb Üstadı İbn Sînâ: Şahsiyetive Eserleri Hakkında Tetkikler (İbn Sînâ'nın 800 yıldönümü), İstanbul 1957.

Grünberg, Teo, Felsefe ve Felsefi Mantık Yazıları, Yapı Kredi Yayınları, İstanbul 2005. -, "Mantık ve Gerçeklik”, Türkiye I. Felsefe Mantık Bilim Tarihi Sempozyumu Bildirileri, Ankara 1991.

Grunberg, Teo ve David, Onart, Adnan, Turan, Halil, Mantık Terimleri Sözlü̆̆̈̈, METU, Ankara 2003.

Hume, David, İnsan Zihni Üzerine Bir Araştırma, çev.: Selmin Evrim, Milli Eğitim Bakanlığı, İstanbul 1986.

-------, İnsan Doğası Üzerine Bir İnceleme, çev.: Aziz Yardımlı, İdea, Yay., İstanbul 1997.

Irzık, Gürol, "Yanlışlamacı Bilim Felsefesi: Genel Bir Değerlendirme", Felsefe Tartışmaları, İstanbul 2001.

İbn Haldun, Mukaddime, tahk.: Ali Abdulvahid Vafi, Daru Nahdati Misır, Misır trs.

İbn Sînâ, "el-İlahiyat", Kitâbu'ş-Şîfâ, tahk.: G. C. Kanavati, Said zayed, ts.

-----, Kitabu'n-Necat, haz.: Macid Fahuri, Beyrut 1985.

,"Mantığa Giriş", Kitâbu'ş-Şîfâ, çev.: Ömer Türker, Litera, İstanbul 2006.

,"II Analitikler/Burhan", Kitâbu'ş-Şîfâ, çev.: Ömer Türker, Litera, İstanbul 2006. İşaretler ve Tenbihler, çev. A. Durusoy, M. Macit, E. Demirli, İstanbul 2005.

-_'Uyunu'l-Hikme", İbn Risaleleri, ed.: Hilmi Ziya Ülken, İstanbul Üniversitesi Edebiyat Fakültesi Yay., Ankara 1953.

, “Uyunu'l-Hikme”, Risaleler, çev.: A. Açıkgenç, H. Kırbaşoğlu, Kitabevi Yay., Ankara 2004. , "el-Burhan/Mantık", Kitabu'ş-Şifa, tahk.: Ebu'l-Ala Afifi, 1385.

İnati, Şemsi, “İbn Sînâ", İslam Felsefesi Tarihi, ed.: S.H.Nasr ve O. Leaman, çev.: Ş. Öçal, H. T. Başoğ lu, Açılım Kitap, İstanbul 2007.

Köz, İsmail, Mantık Felsefesi, Elis Yay., Ankara 2003.

Kulen, Nezahat, Mantık, Kulen Yay., İstanbul 1972.

Kuzgun, Şaban, “İbn Sînâ'nın Hayatı ve Milliyeti” İbn Sînâ Kongresi Tebliğleri, Kayseri 1984.

Lachelier, Jules, Tümevarımın Temeli Hakkında, çev.: H. Ragıp Atademir, İstanbul 1986.

Magee, Bryan, Karl Popper'in Bilim Felsefesi ve Siyaset Kuramı, çev.: Mete Tunçay, Remzi Yay., İstanbul 1990.

Marmura, Michael E., "Avicenna”, The Encyclopedia of Philisophy, New York 1967. 
Mene, Albert, Mantığa Giriş, çev.: Lokman Çilingir, Elis Yay., Ankara 2005.

Mengüşoğlu, Takiyettin, Felsefeye Giriş, Remzi Yay., İstanbul 1983.

Mcginnis, John, "Scientific Methodologies in Medieval Islam", Journal of The History of Philosophy, say1: 41, no: 3, Temmuz 2003.

Medkur, İbrahim, Takdim, “İbn Sînâ", el-İlahiyat/Kitâbu'ş-Şîfâ içinde, tahk.: G. C. Kanavati, Said zayed, ts.

-, "Fârâbî", İslam Düşünce Tarihi içinde, çev.: Osman Bilen, İnsan Yay., İstanbul 1990.

Nesin, Ali, Önermeler Mantı̆̆ı, Yay., İstanbul 2004.

Öner, Necati, Klasik Mantık, Ankara Üniversitesi İlahiyat Fakültesi Yay., Ankara 1991.

Özlem, Doğan, Siyaset, Bilim ve Tarih Bilinci, İnkilap Yay., İstanbul 1999.

Popper, Karl R., Bilimsel Araştırmanın Mantı̆̆ı, çev.: İlknur Aka, İbrahim Turan, YPK, İstanbul 1998. , Açık Toplum ve Düşmanları, çev.: Harun Rızatepe, c. 2, İstanbul 1994.

Rescher, Nicholas, The Develepment of Arabic Logic, Pittsburgh, 1964.

Reichenbach, Hans, Bilimsel Felsefenin Doğuşu, çev.: Cemal Yıldırım, Remzi Kitabevi, İstanbul 1981.

Russel, Bernard, Felsefede İlmi Metod, çev.: Hamdi Akverdi, İstanbul 1940.

Street, Tony, "Mantık” İslam Felsefesine Giriş, ed.: P.Adamson, R.Taylor, çev.: Cüneyt Kaya, Küre Yay., İstanbul 2007.

Swinburne, Richard, “Tümevarımlı Kanıtlar” çev.: Turan Koç, Erciyes Üniversitesi Illahiyat Fakültesi Dergisi, say1: 8, Kayseri 1992.

Şehristânî, Filozoflarla Mücadele, çev.: Aygün Akyol, Aytekin Özel, Litera Yay., İstanbul 2010.

Taylan, Necip, Mantık, Marmara Üniversitesi İlahiyat Fakültesi Vakfi Yay.,İstanbul 1996.

Tusî, Nasiruddin, eş-Şerhu'l-İşarat ve't-Tenbihat, tahk.: Süleyman Dünya, Beyrut 1992.

Ülken, H. Ziya, “İbn Sînâ”, İA, Milli Eğitim Bakanlığı, İstanbul 1968.

İslam Düşüncesi, İstanbul 1995.

Weber, Alfred, Felsefe Tarihi, çev.: H. Vehbi Eralp, Sosyal Yay., İstanbul 1998.

Wisnovsky, Robert, "İbn Sînâ ve İbn Sînâcı Gelenek” İslam Felsefesine Giriş (The Cambridge Companion to Arabic Philosophy), ed.: Peter Adamson, Richard C. Taylor, çev.: M. C. Kaya, Küre Yay. Istanbul 2007.

Yaren, Tahir, İbn Sînâ Mantı̆̆ına Giriş,Yay., Ankara 2003. 